\title{
Comparative Leaf Proteomics of Drought-Tolerant and -Susceptible Peanut in Response to Water Stress
}

Ramesh Katam ${ }^{1}$, Katsumi Sakata ${ }^{2}$, Prashanth Suravajhala ${ }^{3}$, Tibor Pechan ${ }^{4}$, Devaiah M Kambiranda ${ }^{5}$, Karamthot Sivasankar Naik ${ }^{6}$, Baozhu Guo $^{7}$, Sheikh M Basha ${ }^{5}$

${ }^{1}$ Department of Biological Sciences, Florida A\&M University, Tallahassee FL 32307 USA; ${ }^{2}$ Department of Life Science and Informatics, Maebashi Institute of Technology, 460-1 Kamisadori, Maebashi, Gunma 371-0816, Japan; ${ }^{3}$ Bioclues.org, Kukatpally, Hyderabad, India; ${ }^{4}$ Institute of Genomics, Biocomputing and Biotechnology, Mississippi Agricultural and Forestry Experiment Station, Mississippi State University, MS 39759 USA; ${ }^{5}$ College of Agriculture and Food Science, Florida A\&M University, Tallahassee, FL 32307 USA; ${ }^{6}$ ANGR Agricultural University, Lam, Guntur, AP India; ${ }^{7}$ USDA-ARS, Crop Protection and Management Research Unit, Tifton, GA USA

*Corresponding author

Email: ramesh.katam@gmail.com

Telephone: $850-561-2740$

Fax: 850-561-2996

*Department of Biological Sciences, College of Science and Technology, Florida A\&M University, 1530, MLK Blvd, Tallahassee, FL 32307

Running Title: Proteome changes to water stress in peanut 


\begin{abstract}
Water stress (WS) predisposes peanut plants to fungal infection resulting in pre-harvest aflatoxin contamination. Major changes during water stress including oxidative stress, lead to destruction of photosynthetic apparatus and other macromolecules within cells. Two peanut cultivars with diverse drought tolerance characteristics were subjected to WS, and their leaf proteome was compared using two-dimensional electrophoresis complemented with MALDI-TOF/TOF mass spectrometry. Ninety-six protein spots were differentially abundant to water stress in both cultivars that corresponded to 60 nonredundant proteins. Protein interaction prediction analysis suggests that 42 unique proteins showed interactions in tolerant cultivar while 20 showed interactions in the susceptible cultivar, activating other proteins in directed system response networks. Four proteins: glutamine ammonia ligase, chitin class II, actin isoform $\mathrm{B}$, and beta tubulin, involved in metabolism, defense and cellular biogenesis, are unique in tolerant cultivar and showed positive interactions with other proteins. In addition, four proteins: serine/threonine protein phosphate PP1, choline monooxygenase, peroxidase 43 , and SNF1-related protein kinase regulatory subunit beta-2, that play a role as cryoprotectants through signal transduction, were induced in drought tolerant cultivar following WS. Eleven interologs of these proteins were found in Arabidopsis interacting with several proteins and it is believed that similar mechanisms/pathways exist in peanut.
\end{abstract}

Key words: Drought tolerance, leaf proteins, protein-protein interaction, twodimensional electrophoresis, water stress 


\section{Introduction}

Peanut (Arachis hypogaea L.) is one of the world's most important grain legumes. It is primarily grown for high quality edible oil and protein and it is the third most important source of plant protein [1]. A majority of peanut production occurs in semiarid regions of the world, where seasonal drought causes considerable reductions in plant growth, yield, and quality. Furthermore, drought enhances the infestation of Aspergillus flavus, leading to aflatoxin contamination of peanut seed thereby making them inedible for humans and livestock [2]. In addition, drought affects the ability of peanut seed to produce phytoalexins, resulting in aflatoxin contamination [3]. One of the major known molecular responses that plants exhibit to drought stress is the alteration of gene expression in relation to different pathways associated with stress perception, signal transduction, regulators and the synthesis of a number of stress related compounds [4]. These conditions postulate to alleviate the effect of stress and lead to the adjustment of the cellular environment conferring plant tolerance [5]. Genes differentially expressed in response to drought were identified using the cDNA microarray, and the gene expression levels were validated using real time PCR, resulting in the identification of new genes that may play a role in plant response to drought [6-8]. However, thorough understanding of the molecular changes that occur during water stress (WS) are limited [9], mainly due to low polymorphism in the peanut, which exhibits a narrow genetic base showing low genetic variation [10-12].

Water stress (WS) induces changes in cellular and biochemical components during which signaling cascades are initiated, leading to the activation or suppression of certain genes $[13,14]$. The changes in gene expression lead to the modulation of proteins 
involved in the stress. Therefore, analysis of proteins is critical to define functional genomics linking proteins to genomic repertoire. Most cellular processes are regulated by protein-protein interactions (PPI), post-translational protein modifications, and enzymatic activities, which cannot be identified by gene expression studies.

Proteomics and bioinformatics approaches are increasingly being applied to address biochemical and physiological effects in response to biotic and abiotic stresses in various plants [15-21]. Two-dimensional electrophoresis (2-DE) has been successfully used to discover genetic variation among cultivars [22], post-translational products of various genes in several plant species subjected to a wide range of abiotic stresses such as UV radiation, heavy metals, saline, and drought [23-26]. Over hundred proteins were identified using high-throughput 2-DE implicated in cell wall modification, signal transduction, metabolism, and cell defense in the cell wall and extracellular matrix in chickpea leaves exposed to dehydration stress [27].

Until now, 2-DE proteomic studies of peanut have enabled identification and characterization of seed proteins from cultivated peanut and identification of genetic variation among peanut cultivars $[28,29]$. Proteomics has been used to successfully identify diverse seed storage proteins, various aspects of leaf development, and genetic diversity in sub species of Arachis [30,31]. Drought tolerant (DT) cultivars maintained seed protein content in high abundance during WS while susceptible cultivars failed to maintain their quantities, suggesting the potential use of these protein(s) as markers to screen peanut germplasm for drought tolerance from these studies. In peanut, quantitative differences in proteins were analyzed using 2-DE for selected US minicore germplasm and 49 proteins were identified in leaf responding to water stress [32]. However, the 
protein-protein interactions (PPI) in peanut cultivars have not been studied. Although PPI analysis was carried out for the development of the basal region in rice seedlings [33] and early-stage soybean seedlings under flooding stress and non-stress [34], a comparison between PPI of tolerant and susceptible cultivars has not been reported in peanut. Over 200 peanut cultivars obtained from USA and India, were evaluated for determining genetic diversity in leaf and seed protein composition and their response to water stress [35]. We have characterized leaf proteome of tolerant peanut cultivar Vemana as a first step towards to identifying compositional changes in their proteins pertaining to various stresses [36]. In this study, we have identified water stress responsive (WSR) proteins of the two contrast cultivars for drought tolerance to unravel the underlying mechanisms involved in their differential response to dehydration. Vemana is known to be highly drought-tolerant and has an excellent yield, while Florunner is a popular cultivar despite its susceptibility to drought. Vemana is widely grown under rain-fed conditions in semiarid regions tolerant to drought and has recorded high pod yield even in drought years [37]. Florunner was derived from a cross between early runner and Florispan grown in US [38]. The present study reveals the identity and functions of low and high abundant proteins and newly induced leaf proteins in DT and DS cultivars due to water stress, and discusses their possible role in tolerance mechanism. Changes in leaf proteome revealed the ability of tolerant cultivar to withstand dehydration-induced damage. A catalog of the proteome changes occurring under water stress, as determined by proteome profiling, was constructed and further coordination of proteins within the tissue was investigated. This is also our first report on peanut PPI analysis based on a differential equation model of expression profile. 


\section{Materials and Methods}

Plant material, growth and maintenance: Peanut (Arachis hypogaea L.) cultivars with varying drought tolerance characteristics were obtained from ANGR Agricultural University, India and University of Florida, Mariana, FL. Two distinct cultivars, droughttolerant (Vemana) and drought-susceptible (Florunner), were used in this study. Seeds were surface sterilized with $70 \%$ ethanol and washed with water. Peanut plants were grown individually in 10-liter pots containing MetroMix-702 soil (Scotts Company, Marysville, USA) at USDA facility, Tifton, GA. The plants were maintained at a temperature of $30 / 28^{\circ} \mathrm{C}$ day/night, in natural light conditions and $5 \%$ relative humidity. Sodium lamps were used to maintain 15/9 light /dark photoperiod $(270 \mathrm{~mol} / \mathrm{sec})$.

Water stress treatment and determination of soil water potential: An average of 200 $\mathrm{ml}$ of water was added to each control treatment to maintain Field Capacity (FC) at $\sim 100 \%$ until harvest. The gradual water stress was implicated on 50-day old plants for 15 days by withdrawing water. Fully expanded mature leaves were collected in six replicates from an irrigated control while collections for stressed plants were carried out at three different periods: (i) 3 days after stress (DAS), (ii) 7 DAS, (iii) 15 DAS. To randomize biological variations, 50 leaflets were collected from four to five plants randomly down the main stem between 4-10 nodes. Collected leaves were pooled, frozen in liquid nitrogen and stored at $-80^{\circ} \mathrm{C}$ until further use. For all plants in the experiment, soil water potential was measured in triplicate at 3-day intervals, using Quick Draw soil moisture probe (Model 2900F1, Soil moisture Equipment Corp., Santa Barbara, CA).

Measurement of relative water content: Leaf tissues were collected at regular intervals from both control and stressed plants and relative leaf water content was measured as 
fresh weight, after collection, and fully turgid weight, after $24 \mathrm{~h}$ of rehydration [39]. Then, the tissues were oven dried at $80^{\circ} \mathrm{C}$ for $48 \mathrm{~h}$ to calculate dry weight in triplicates. Relative water content was calculated as follows: Relative Water Content $=($ Fresh weight - Dry weight) / (Turgid weight - Dry weight).

Leaf chlorophyll content: Leaf chlorophyll content was measured using a SPAD chlorophyll meter (SPAD 502, Minolta, Tokyo) and recorded at each time point.

Electrolyte leakage assay: Electrolyte leakage was assayed by estimating the ions leached from the leaflets. Samples from control and treated plants were collected and placed in $20 \mathrm{ml}$ of water. After incubating for $4 \mathrm{~h}$ at room temperature, the conductivity $\left(\mathrm{C}_{1}\right)$ was recorded using a conductivity meter. The second set of tissues was autoclaved in water and its conductivity was recorded $\left(\mathrm{C}_{2}\right)$. Electrolyte leakage was calculated using the formula: $\left[1-\left(\mathrm{C}_{1} / \mathrm{C}_{2}\right) \times 100\right]$.

Measurement of total sugars: Total soluble sugars in the ethanol soluble fractions were determined using a modified extraction method [40]. Leaf tissue (300 $\mathrm{mg}$ ) was crushed in $5 \mathrm{ml}$ of $98 \%$ ethanol. The insoluble fraction of the extract was washed with $70 \%$ ethanol. All soluble fractions were centrifuged at $3500 \mathrm{~g}$ for $10 \mathrm{~min}$. The supernatants were used for determination of soluble sugars using anthrone reagent. Glucose was used for the determination of the standard curve.

Ascorbate peroxidase assay: The leaf tissue was homogenized in $50 \mathrm{mM}$ of $\mathrm{KPO}_{4}$ buffer ( $\mathrm{pH}$ 7.0). The homogenate was centrifuged at $16,000 \mathrm{~g}$ for $20 \mathrm{~min}$ at $4^{\circ} \mathrm{C}$. The supernatant was transferred and ascorbate peroxidase was assayed from the decrease in absorbance at $290 \mathrm{~nm}$ as ascorbate is oxidized by its activity [41]. Absorbance of nonenzymatic oxidation of ascorbate by $\mathrm{H}_{2} \mathrm{O}_{2}$ was used as control. 
Total protein extraction: Leaf tissue $(2 \mathrm{~g})$ was ground into a powder under liquid nitrogen, suspended in $5 \mathrm{ml}$ solution of acetone containing 20\% TCA, and then homogenized for $2 \mathrm{~min}$ on ice. The homogenate was centrifuged $\left(20000 \mathrm{~g}\right.$ at $4^{\circ} \mathrm{C}$ for 15 min) and the resulting pellet was washed three times with ethanol, and then once with acetone. Total Protein was extracted using $500 \mu$ of rehydration buffer (7 M urea, 2\% CHAPS [w/v], $2 \mathrm{M}$ thiourea, 0.2\% DTT [w/v]), as described previously [36]. Protein concentration was measured using the Bradford method [42].

2-DE Protein mapping and gel image analysis: An aliquot $(250 \mu \mathrm{g}$ in $150 \mu \mathrm{l})$ of the protein extract was loaded on to the tube gels and isoelectric focusing was performed as described earlier [36]. Electrophoresis was carried out in a BioRad Protein II system at a constant current of $20 \mathrm{~mA} / \mathrm{gel}$. The gels were stained with colloidal Coomassie Brilliant Blue R-250 to visualize protein spots. Gels were scanned using gel documentation system (Gel Doc XR, BioRad, Hercules, CA) and analyzed using PD Quest software, V8.0.1 to normalize the gel images and to create a master gel profile. For normalization and consistency, three replicated gels from each treatment were used. The gel area (at least $95 \%$ of the total gel area) was defined using selected proteins bordering each side of the gels as landmarks. Protein spots across the gel replicates were matched by landmarks and positioned consistently, in all replicated gels. The Analysis Set (master gel profile), derived from three replicated gels of matched spots that were present on all the gels, was created, and the spots were analyzed and characterized. The master profiles representing each treatment were compared to determine the differences in relative protein abundance. Principle Component Analysis of protein expression data derived from control and stress treatments was performed using the XLSTAT software (Addinsoft, NY). 
Mass spectrometry and protein identification: Protein spots showing quantitative variation were excised from 2-DE gels and in-gel trypsin digestion was performed as per the standard procedures [43]. Peptide mass spectra were collected on MALDI-TOF/TOF, (ABI 4700, AB Systems, Foster City, CA) and protein identification was performed using the automated result dependent analysis (RDA) of ABI GPS Explorer softwareV3.5. The method's critical parameters were chosen as follows: Digestion enzyme $=$ trypsin with one missed cleavage, MS (precursor-ion) peak filtering $=800-4000 \mathrm{~m} / \mathrm{z}$ interval, monoisotopic, minimum signal-to-noise $(\mathrm{S} / \mathrm{N})$ ratio $=10$, mass tolerance $=100 \mathrm{ppm}$. MSMS (fragment-ion) peak filtering: monoisotopic, $\mathrm{M}+\mathrm{H}^{+}$, minimum $\mathrm{S} / \mathrm{N}=3, \mathrm{MS} / \mathrm{MS}$ fragment tolerance $=0.2 \mathrm{Da}$. During the initial MS scan, data was analyzed as peptide mass fingerprinting (PMF). GPS Explorer ${ }^{\mathrm{TM}}$ Software introduces a unifying parameter called confidence interval (CI), which rates the confidence level of the MASCOT (Matrix Science) protein score or ion score (for each MS/MS event). Proteins that were identified by PMF with high confidence (C.I.\% > 95\%) were automatically subjected to in silico trypsin digestion and their five most prevalent corresponding peptides-precursor ions present in the MS spectra were selected for RDA_1 (top protein confirmation) MS/MS analysis. The sample spots not yielding high confidence ID after PMF and RDA_1 analysis underwent the second MS/MS scan (RDA_2) by selecting the first thirteen most intensive precursor ions in the MS spectra for MS/MS analysis. The spectral data from all three scans (PMF, RDA_1 and RDA_2) were searched against Viridiplantae database using the algorithm [44]. At least 2-peptide matches were required for positive identifications. 
Functional annotation and predicting subcellular localization: The protein spots that were identified from 2-DE were mapped to Uniprot. The accessions were queried using Batch Entrez, which is an automated system used to retrieve sequences mapped to different proteins. Gene ontology of identified proteins was performed using Blast2Go v2.3.6 [45]. A file of FASTA sequences of the identified and/or quantified protein set was batch retrieved from NCBI. Blast2Go was fed with the FASTA file and subsequently map GO, EC, Interpro terms and then to annotate the sequences. Target $\mathrm{P}$ program was used for functional classification and subcellular localization [45].

Hierarchical cluster analysis of expression profiles: Ninety-six data series of induction along the time points were divided into clusters based on a distance among the data series for DS and DT cultivar separately. The distance was measured by a distance function based on a logarithmic scale [46]. A hierarchical clustering was performed using the clustering method and un-weighted pair group method with arithmetic mean.

Protein-protein interaction analysis: Mathematical gene interaction network optimization software (MINOS) was used to estimate protein interactions in the tolerant and susceptible cultivars separately. A mathematical approach was used to estimate the interactions for the DT and DS cultivars. This approach was based on the S-system differential equation that simulated an expression profile [34]. Protein orthologs were identified in Arabidopsis using ENTREZ query and UNIPROT and the sequences that were found to be redundant were excluded. Interactions for these proteins were further analyzed using Arabidopsis thaliana protein interaction database [47].

Quantitative reverse transcription polymerase chain reaction analysis (RT- qPCR): Leaf samples $(100 \mathrm{mg})$ collected from all stages of treatment were ground in liquid 
nitrogen. Total RNA was isolated using a modified CTAB-based protocol [48] and further purified with the RNeasy Plant Mini kit (Qiagen, Valencia, CA, USA). Total RNA from each sample was reverse-transcribed using an iScript cDNA Synthesis kit (Bio-Rad, Hercules, CA, USA). Primers were designed using NCBI database and the Primer 3Plus as shown in Suppl. Table I [49]. RT- qPCR was performed on Bio-Rad iCycler using the cDNA product $(20 \mathrm{ng})$ in a $20 \mu \mathrm{l}$ reaction mixture that includes $1 \mu \mathrm{L}$ of forward and reverse primers of the corresponding transcripts, using $\mathrm{SYBR}^{\circledR}$ Green Universal mix (BioRad). PCR conditions were optimized for amplification of each gene before conducting relative quantitative experiment, using the specific primer pair and visualizing the PCR products by agarose gel electrophoresis. The PCR conditions were as follows: $95^{\circ} \mathrm{C}$ for $30 \mathrm{~s}$, then 45 cycles of $95^{\circ} \mathrm{C}$ for $10 \mathrm{~s}$ and $60^{\circ} \mathrm{C}$ for $30 \mathrm{~s}$. Data was acquired at $60^{\circ} \mathrm{C}$. Data was normalized using the actin gene $\mathrm{Ct}$ value and extent of change was calculated using the $\mathrm{Ct}$ value of the calibrator (control samples -no water stress treatment) using the formula $2^{-\Delta \Delta \mathrm{CT}}$. All assays for each gene were performed using five independent biological replicates for each gene in each treatment under identical conditions. The statistical significance of the results was evaluated with the Student's ttest $(\mathrm{p}<0.05)$. All calculations were performed using Graphpad software V5.0.

\section{Results:}

Two contrasting cultivars for drought (Vemana and Florunner) were used to study the relative abundance of proteins affected by water stress (WS). Fifty-day old peanut plants were subjected to WS by withholding irrigation for 15 days. The visual symptoms, such as wilting, appeared on the plants after 3 days with the damage escalating until it became irreversible (in 15 days). During this period soil water content decreased from 
$19.2 \%$ at $25 \%$ Field Capacity (FC) to $4.8 \%$. The soil water potential on $3 d, 7 d$ and $15 d$ of WS were measured as 10,15 and $25 \mathrm{kPa}$, respectively showing progressive water deficit during the stress treatment.

Relative water content (RWC): Upon applying dehydration stress, both Vemana and Florunner exhibited a steady decrease in RWC at the $3^{\text {rd }}$ day. However, after 3 days, a constant decline in RWC in Florunner indicated the severity of dehydration. Vemana, which is drought tolerant, remained stable with $76 \% \mathrm{RWC}$ at 15 day stress period, while RWC of Florunner decreased to 57\% (Figure 1a).

Electrolyte leakage: The capacity to avoid or repair membrane damage during dehydration processes can be measured by the status of electrolyte leakage in both DT and DS cultivars under dehydration. The electrolytes of Vemana were found to maintain itself constantly until 3 days of WS, showing a marginal increase in the later stages of dehydration until 15 days stress (Figure 1b). Conversely, Florunner showed a sharp rise in electrolyte leakage to the WS.

SPAD chlorophyll content: To understand the photosynthetic capabilities of tolerant and susceptible cultivar, the status of photosynthetic pigments was determined under dehydration. The SPAD value for Vemana is $37.6 \%$ and $30.76 \%$ for Florunner. Under dehydration stress (15 days), the SPAD values fell to $34.2 \%$ for Vemana and $23.8 \%$ for Florunner (Figure 1c).

Total sugars: Vemana and Florunner cultivars are not similar in their production of soluble sugars in leaves under control conditions. Florunner has greater amounts of soluble sugars than Vemana (Figure 1d). However, the content of soluble sugars 
increased 2-fold in Vemana in response to stress at 15 days, while in Florunner there was a slight reduction in sugar content.

Water stress responsive proteins: Analysis of the 2-DE gels by digital image analysis and visual spot-by-spot validation of the match derived from gels indicated that more than $90 \%$ of the proteins on 2-DE were of high quality (Table 1). The analysis also revealed 300 detected protein spots in DT and 298 in DS cultivars, respectively. Comparison of unstressed control DT and DS cultivar protein profiles revealed five unique protein spots ( $\# 38,39,64,66$, and 67$)$ in DT and another five unique protein spots (\#88, 89, 90, 91, and 92) in DS cultivar. Tolerant cultivar showed a slight increase of $1.3 \%$ in total proteins, contrasting susceptible cultivar that showed $9 \%$ decrease in their proteins due to water stress.

Protein spots demonstrating a ratio of at least 1.5 fold between control and stressed plants of either DT or DS were defined as relative abundant proteins, based on the co-relation coefficient $(r>0.95)$ [50]. Comparative analysis of protein profiles revealed ninety-six proteins' quantitative variation following water stress (82 proteins common to both cultivars, 5 each unique protein spots to DT and DS, and 4 newly induced in DT cultivar) that satisfies the 95\% confidence interval ( $\mathrm{p}$ value $\leq 0.05$ ) (Figure 2). Principal component analysis (PCA) on this data set was performed to identify the relative contributions between stressed and control individuals and between tolerant and susceptible cultivars. The analysis in DT showed $91 \%$ variability and in DS, $85.3 \%$ variability among protein spots compared to their respective controls. The unsupervised PCA demonstrated that tolerant cultivar segregated into stress and control groups showed maximum change in protein quantities compared to susceptible cultivar (Figure 3). 


\section{Protein identification and characterization of water stress responsive proteins}

(WSR): Ninety-six differentially abundant WSR proteins across 2 or more time points were identified by mass spectrometry in either DT or DS cultivars with $95 \%$ confidence interval (Table 2). All of these 96 spots accounted for 60 non-redundant proteins, since similar proteins were spotted in multiple locations with differences in their isoelectric points and/or molecular weights on 2-DE gel (Suppl. Figure I). The identification of multiple identities suggests the possible dehydration-induced post-translational modification(s) of the candidate proteins, isoforms or members of multigene families. The spectra of some proteins detected in two or more distinct spots indicate the truncation of their N-terminus and/or C-terminus (Suppl. Table II).

Functional classification of WSR proteins: Water stress responsive proteins were categorized into seven functional groups based on their physiological role in plant representing $83 \%$ of proteins (Suppl. Table III). The identified proteins were associated with photosynthesis (34), metabolism (28), protein synthesis (15), transport (10), stress related (4), signal transduction and cellular biogenesis (5). The protein data was also analyzed to determine their association with individual organelles. The results showed that the majority of the proteins are localized in chloroplast (65) (Figure $4 \mathrm{a} \& \mathrm{~b}$ ).

\section{Expression clustering and dynamics of the of WSR protein networks in DT and DS}

cultivars: The fold change in relative abundance of WSR proteins during the time course of stress are described under major functional categories through cluster analysis to elucidate various regulatory pathways operative at various stress levels (Figure 5). Profiling of the 96 proteins was carried out at 4 time points over $(0,3,7$, and $15 \mathrm{~d})$ in 
terms of fold change to stress (Suppl. Figure II). Two-DE Gels with relative abundance of selected proteins are represented in Suppl. Figures III and IV.

The WSR proteins were grouped into five clusters in both cultivars and the clusters with $n<6$ were used for the study of co-expression patterns (Figure 6). In the DT cultivar, majority of proteins have shown an upward trend with water stress. The most abundant group was cluster T-V with 68 proteins gradually showing high abundance to water stress at each time-point. Cluster T-V represented majority of proteins related to photosynthesis (20), followed by metabolism (17), protein synthesis (13) and defense (4). Cluster T-I, which included proteins classified into metabolism, showed a dramatic upward trend and were newly induced to water stress in DT. Cluster T-IV was rich in photosynthetic proteins. Clusters T-II and T-III have an exceptional trend in DT with a majority of these proteins gradually reduced in abundance in water stressed tissue.

Proteins in DS cultivar were grouped in 5 clusters. The most abundant cluster, SIII included proteins related to photosynthesis. Three clusters of DS (S-I, S-II and S-III) showed gradual reduction in their protein abundance to WS. Most of these proteins were associated with protein synthesis, photosynthesis, metabolism and transport. The protein abundance was remarkably decreased in S-I cluster, compared to S-II and S-III. Members of cluster S-IV included proteins related to protein synthesis and photosynthesis showed slightly high in their abundance to water stress. Members of clusters S-V that included proteins involved in protein synthesis, photosynthesis, metabolism, transport, defense, signal-transduction showed a considerably downward trend during water stress.

Putative protein interaction networks of DT and DS cultivars to water stress: Time course expression data was used to estimate the interaction among the proteins in both 
DT and DS cultivars to understand the altered biosynthetic process during the stress. Forty-two proteins showed positive interaction in DT while 20 proteins in DS showed the same, indicating the level of interactions in response to stress (Suppl. Table IV). A total of 17 proteins related to metabolism in Vemana had high intensities (>0.9) compared to 6 in Florunner, followed by 4 defense proteins in DT and 1 in DS, 3 signal transduction proteins in DT and none in DS cultivars (Figure 7).

Ortholog protein interactions in Arabidopsis: The bona fide protein interactors determined through Yeast 2 Hybrid, co-expression, Gene fusion, and Gold Standard Positive methods were further analyzed to investigate functional links between different proteins and developed protein interaction networks (Suppl. Figure V). Out of 96 water stress responsive proteins, orthologs of 17 protein spots, corresponding to 11 nonredundant proteins showed interactions in Arabidopsis (Table 3).

mRNA expression analysis of water stress responsive (WSR) proteins: Selected WSR proteins, either unique to the stress response or showing over 2- fold change in their abundance, were selected for mRNA expression analysis. Leaf tissue samples from control and water stressed plants were collected for mRNA extraction and then analyzed for RT-qPCR. Upon water stress, the mRNA expression levels of CA, CALR, PER43, PRx, gapA1, APX, and CHMO were up regulated in DT cultivar, while they were down regulated in DS (Figure 8). The mRNA expression of EF1 and PAP1 were up regulated in both DT and DS cultivars.

Determination of antioxidant activity: In order to determine the functional aspect of ascorbate peroxidase (APX) enzyme, its activity was measured in both cultivars at 
different levels of water stress. While there was a 2-fold increase in activity in DT, there was no significant change in APX activity of DS cultivar (Figure 9).

\section{Discussion:}

One of the significant early symptoms of water stress is the decrease in leaf relative water content (RWC), representing variations in water potential, turgor potential and osmotic adjustment in plant tissues [51]. It is likely that higher RWC at lowered water potential maintains the growth and metabolic activities, including photosynthesis. The ability of drought tolerant cultivar to maintain high RWC may be due to the more osmotic regulation or less elastic nature of its cell wall [52]. However, in drought susceptible cultivar, a constant decline in RWC to WS indicated failure of osmotic adjustment to maintain the turgor pressure in the affected tissues.

\section{A. Effect of water stress on protein synthesis (modification), photosynthesis, and defense related proteins:}

i). Protein synthesis and modification: Two heat shock proteins (HSP) were highly abundant in the tolerant cultivar (DT) but were reduced in the susceptible cultivar (DS). Protein disulfide isomerase-2 (PDI2) was abundant in DT and showed 2-side interaction, while no interaction was shown in DS. PDI2 function as a chaperone, while high abundance of HSP-70 prevents the aggregation of denatured proteins and helps in refolding of non-native proteins by acting as molecular chaperones $[53,54]$. Furthermore, cyclophilin (CYP) and chaperonins were more abundant in DT. CH60 is an essential molecular chaperone in the folding/assembly pathway of RuBisCO in higher plants imparting their basal defense $[55,56]$. In addition, elongation factor, another molecular chaperone, was abundant in water stressed DT [57]. Although the mRNA expression 
levels of EF were increased during water stress in DS, the protein abundance was low at all stress levels in DS cultivar. Similarly, 50S ribosomal protein L12-chloroplastic (RK12) was abundant in DT, and showed a 1-side interaction in DT and no interaction in DS [58]. GrpE Protein homolog facilitates exchange of ADP for ATP and was found high in abundance in DT [59].

ii). Photosynthesis: Maximum number of proteins associated with photosynthesis, such as plastocyanin, chlorophyll a/b binding protein, and $\mathrm{RuBisCO}$, were high in abundance in water stressed DT cultivar. Earlier reports showed reduced amounts of RuBisCO in stressed plants [60], however, in this study, DT cultivar showed high abundance of RuBisCO protein. Enzymes of the Calvin cycle, such as sedoheptulose-1, 7bisphosphatase, NADP-dependent glyceraldehyde-3-phosphate dehydrogenase, and phosphoribulokinase, involved in carbon fixation, were highly abundant in DT. The low abundance of these proteins in DS might cause oxidative stress, leading to the destruction of photosynthetic apparatus, changes in the conformation of chloroplast proteins and thus causing imbalances in the ions and homeostasis of water stressed tissues in susceptible cultivar [61]. Higher abundance of glyceraldehyde phosphate dehydrogenase in the DT cultivar suggests the early acceleration of the glycolytic pathway upon stress. Thus, in Vemana (DT), the photosynthesis mechanism seems to be less affected as is evident from the abundance of more photosynthetic proteins such as photosystem I and II which ensures electron flow to $\mathrm{NADP}+$ to electron transport chain and preventing oxidative stress.

iii). Defense, signal transduction and cellular biogenesis: Tubulin and actin, which play a major role in cytoskeleton re-arrangement [62], were more abundant in stressed tissue of 
DT cultivar. Calreticulin, an important calcium-binding protein, was high in abundance in DT, playing a crucial role in signal transduction, $\mathrm{Ca}^{2+}$ storage and release, protein synthesis, and molecular chaperone activity [63]. Calreticulin mRNA transcript was expressed until stress level 2 in DS; however, it could not translate to protein in stressed tissue. Fibrillin, a structural activity protein, was steadily apparent in DT, while it was low in the DS; although its expression at transcript level was high in DS in response to stress. Fibrillin has a one-sided positive interaction in the DT, while the protein exhibited 2-sided negative interaction in DS cultivar. Putative brassinosteroid insensitive 1associated receptor kinase 1 (OsSERK1), a group of receptor kinases that activates intracellular signaling pathways in response to external stress stimuli [64], was reduced in both DT and DS. However, OsSERK1 exhibited 2-sided interaction in DT, while no interaction was found in DS. PRx has a 2-sided promoting interaction in DT cultivar, whereas this protein exhibits a negative interaction in the DS cultivar. Increased abundance of ascorbate peroxidase enzyme (APX) and the increased activity during the stress in DT contribute to the production of ascorbate through galactose metabolism, and restore the oxidation levels [65]. Although APX did not show any interaction in DT cultivar, this protein exhibited a 2-sided negative interaction in DS cultivar.

\section{B. High abundance of metabolism related proteins involved in cell wall composition} modification in drought tolerant cultivar: Methionine synthase, responsible for Sadenosyl methionine synthesis, was highly abundant in DT. The cumulative function of methionine synthase and methyl transferases provide activated methyl groups in the biosynthesis of lignin monomers, thus strengthening the cell wall components and maintaining their integrity during stress [66]. In addition, glycine rich protein was 
abundant in DT, regulating cell wall composition modification [67]. In contrast, both the proteins were suppressed in DS cultivar to WS.

Proteins involved in carbohydrate metabolism and carbon fixation were found in higher abundance in DT while suppressed in DS, suggesting a transient reduction of carbon flux in DS. Quinone oxidoreductase was increased in abundance in DT due to WS, while it was not detected in stressed tissue of DS cultivar. Carbonic anhydrase (CA), which plays key role in electron transport during photosynthetic process, was highly abundant in the DT cultivar, while it was suppressed in DS following WS. The mRNA expression of CA observed during initial stress point did not translate to protein in the DS cultivar. The protein known to play an anti-oxidative role in overcoming photo oxidative injury and oxidative stress, showed 2-sided interactions, suggesting its response in DT to balance for water stress [68]. The abundance of photorespiration protein glycine dehydrogenase (GLDP2) increased over WS in DT suggests that the plant response to stress damage. Fructose bisphosphate aldolase (FBA2), triosephosphate isomerase (TIM) involved in carbon metabolism, increased in DT under stress condition to provide energy and carbon skeletons [69]. High abundance of transketolase (TKT3) increases the availability of intermediates in both the Calvin cycle and non-oxidative pentose phosphate pathways to maintain the carbon metabolism in DT cultivar [70].

Proteins associated with signaling act as a surveillance system and engage in efficient signaling cascade, which allows for the early detection of any impeding adverse environments. Higher abundance of RNA binding protein in DT and its 2-sided interactions suggests the involvement in post-transcriptional regulatory events in response to changes in environmental conditions [71]. Protein 14-3-3 like was detected in 
higher abundance to WS in DT. These 14-3-3 proteins have ability to bind to signaling proteins, ATPases, protein kinases, phosphatases, and transmembrane receptors that aid in the regulation of stress responsive proteins [72]. The binding of 14-3-3 protein to other phosphorylated stress responsive proteins in Vemana (DT) might result in rapid adaptation of enzymatic activities and metabolic pathways in response to WS.

\section{Potential water stress induced programed cell death in susceptible cultivar:}

Proteins involved in electron transport energy are severely affected to WS in susceptible cultivar. ATP synthase epsilon chain and ATP synthase beta subunit were detected a higher abundance in DT, suggesting their putative role in the cellular process to meet energy demand and alleviate water deficit stress by increasing ATP supply to meet increased stress related energy demand [73]. Elevated levels of Cation/Hydrogen exchanger in DT contribute to $\mathrm{K}^{+}$uptake for turgor generation and to accrue osmotic balance under the stress [74]. In addition, high abundance in Cytochrome $\mathrm{C}$ oxidase subunit 6B-1 (COX) in DT enhances electron transport chain in mitochondria, while the absence of COX in DS due to stress, induced programed cell death [75].

\section{Unique and newly induced proteins to water stress enhanced cytoskeleton and} cell wall component modifications in drought tolerant cultivar: Four proteins, glutamine ammonia ligase, chitin class II, actin isoform B, and beta tubulin, were unique to tolerant cultivar. Glutamate ammonia ligase was detected in high abundance due to WS, has 2-sided interactions, and is known to enhance ammonium assimilation and metabolism [76]. Chitinase class II (Chi2) and actin isoform B showed 2-sided interaction in DT while both the proteins were not present in DS. Chitinase was detected in more abundance in response to environmental stress in majority crop plants, while 
actin responds as drought adaptation, by strengthening the cytoskeleton of the stressed tissue $[77,78]$. The high abundance of beta tubulin to WS suggests the stress-facilitated cytoskeleton remodeling via tubulin in DT.

Four new proteins: serine/threonine protein phosphate (PP1), choline monooxygenase (CMO), peroxidase 43 (PER43) and SNF1-related protein kinase regulatory subunit $B-2$ (KINB1), were induced in DT cultivar following WS, while none of these proteins were detected in the DS. PP1 has a role in signaling pathway to modulate the stress responses [79]. CMO regulates S-adenosyl-L-methionine synthase for betaine synthesis, which protects plant from environmental stress [80]. PER43, one of the ROS metabolizing enzymes localized in the cell wall, is involved in the lignification and suberization of the plant cell wall [81]. Induction of PER43 in DT, both at transcript and protein levels, suggested the positive correlation of enhancement in the biosynthesis of cell wall components, improving cell wall integrity in tolerant cultivar. Induction of KINB1 in Vemana suggests the response to an osmotic stress and its expression is reported to enhance the starch accumulation [82]. Although KINB1 transcript was expressed in DS at initial stress levels, it could not be translated to the protein.

E. mRNA expression profiles: Although most of the mRNA expression levels were in agreement with their protein abundance levels, there was a mixed response of some transcript expression and protein accumulation profiles. For example, APX transcript is not shown but its protein showed in DS at low concentrations. Choline monooxygenase protein was not detected in DS, while its mRNA was expressed in lower amounts. Fibrillin was in low abundance in both cultivars while its transcript expression levels were high in both. Both GapA1 and PRx transcript levels were down regulated, while the 
proteins were more abundant in DS cultivar. PER43 was not detected at both mRNA and protein level in DS cultivar.

F. Ortholog protein interactions in Arabidopsis: Out of 11 interacting unique proteins, 4 were localized in chloroplast, while the remaining 7 localized to mitochondria or other organelles (Table 3). In addition, eight interacting unique proteins showed interactions (as shown in MINOS, Figure 7) in DT and six unique proteins in DS cultivar, respectively. The four proteins localized to chloroplast and all their interacting partners, also localized to chloroplast, were deemed to be significant because of ATP synthesis in leaf tissue. The interactant of ATPER1, namely ATPERXQ, may be piggybacking between chloroplast and mitochondria, shown through co-expression networks. Recent progress on evaluating the PPI was made using six-point classification scoring schema. The methods proposed have shown a bona fide approach of annotating proteins to check whether or not the interactors were present in the organism of interest [83].

\section{Conclusions:}

The accumulation of sugars plays an important role in drought avoidance through maintaining relative water content, osmotic adjustment with the high abundance of proteins and regulating redox status. The main effects of the mimicked drought were detected through changes in the abundance of proteins involved in signal perception, defense, metabolism, and photosynthesis, suggesting a connection to those processes involved in drought avoidance and/or tolerance. Vemana, the drought tolerant cultivar, showed a high abundance of these proteins compared to Florunner. The enzymes involved in cell wall lignification, such as methionine synthases and peroxisome 43, function as a constitutive physical barrier to minimize the water loss (Figure 10). Water 
stress apparently induces the production of signaling proteins including cyclophilin, choline monooxygenase, and serine/threonine protein phosphate PP1 in tolerant cultivar. The 14-3-3 protein interacts with $\mathrm{H}+$ ATPases and protein kinases, and regulates the abundance of other water stress-responsive proteins, such as ascorbate peroxide, and helps to prevent lipid peroxidation and protein oxidation of cell wall components. Proteins: glutamate ammonia ligase, chitin class II, actin isoform B and beta tubulin were detected in Vemana act to provide additional stress induced signal perception and transduction. More proteins showed interactions in DT compared to DS cultivar. Interactions between the proteins belong to metabolism, defense and signal transduction in DT cultivar provide enhanced tolerance to the plant. Whether or not the interactants have been orthology-mapped in the peanut is unknown until functional linkages in the peanut are statistically implemented. We contemplate that the abundance of the aforementioned proteins influence the other proteins, however, additional evaluation based on a pull down assays on specific interlog are required to determine their interactions. The candidate proteins can further be used as a bait to explore more possible interactants.

Acknowledgement: RK thankfully acknowledges the financial support from NSF-REU (1156900), Faculty Research Award Program (002257) to conduct this research, and to Japan Society for the Promotion of Science (S-10187, S-14088) to support collaborative efforts. Dr. Barry L Tillman, UF/IFAS, Mariana FL provided peanut germplasm. Ms. Kaylee Castle proof read the manuscript and Ms. Khadijah Weathers assisted in graphics.

\section{References}


[1] R.O. Hammons, The origin and history of the groundnut, in J. Smartt (Ed.), The groundnut crop: A scientific basis for improvement, Chapman Hall, London, UK, 1994, pp. 24-39.

[2] R.J. Cole, T.H. Sanders, R.A. Hill, P.D. Blankenship, Geocarposphere temperatures that induce pre-harvest aflatoxin contamination of peanuts under drought-stress, Mycopathologia 91(1985) 41-46.

[3] J.W. Dorner, R.J. Cole, T.H. Sanders, P.D. Blankenship, Interrelationship of kernel water activity, soil temperature, maturity, and phytoalexin production in pre harvest aflatoxin contamination of drought stressed peanuts, Mycopathologia 105 (1989) 117128.

[4] R. Katam, V.A. Gottschalk, P. Survajahala, G. Brewster, P. Payton, K. Sakata, C. Lee, C. Williams, B. Guo, L.M. Latinwo, Advances in Proteomics Research in Peanut Genetics and Breeding, in: (Eds.): N. Mallikarjun and R. Varshney, Genetics, Genomics ad Breeding of Peanuts. CRC Press, Science Publishers, Boca Raton, (2014) pp. 161-177. [5] S. Ramanjulu, D. Bartels, Drought and desiccation induced modulation of gene expression in plant cell environment, Plant Cell Environ. 25 (2002) 141-151.

[6] M. Luo, X.Q. Liang, P. Dang, C.C. Holbrook, M.G. Baucher, R.D. Lee, B. Guo, Microarray-based screening of differentially expressed genes in peanut in response to Aspergillus parasiticus infection and drought stress, Plant Sci. 169 (2005) 695-703.

[7] D.M. Kambiranda, G. Bali, T.N. Athmaram, S.M. Basha, Identification of two new genes from drought tolerant peanut up-regulated in response to drought, Plant Growth Regul 52 (2007) 249-258.

[8] P. Payton, K.R. Kottapalli, D. Rowland, W. Faircloth, B. Guo, M. Burow, N. Puppala, 
M. Gallo, Gene expression profiling in peanut using high density oligonucleotide microarrays, BMC Genomics, 10 (2009) 265.

[9] K.N. Drame, D. Clavel, A. Repellin, C. Passaquet, Y. Zuily-Fodil, Water deficit induces variation in expression of stress responsive genes in two peanut (Arachis hypogaea L.) cultivars with different tolerance to drought, Plant Physiol Biochem., 45(2007) 236-243.

[10] H.T. Stalker, L.G. Mozingo, Molecular markers of Arachis and marker-assisted selection, Peanut Sci., 28 (2001) 117-123.

[11] H.D. Upadhyay, P.J. Bramel, R. Ortiz, S. Singh, Developing a mini core of peanut for utilization of genetic resources, Crop Sci., 42 (2002) 2150-2156.

[12] H.H. Wang, P. Khera, B. Huang, M. Yuan, R. Katam, W. Zhuangm, K. HarrisShultz, K.M. Moore, A.K. Culbreath, X. Zhang, R.K. Varshney, L. Xie, B. Guo, Analysis of genetic diversity and population structure of peanut cultivars and breeding lines from China, India and the US using SSR markers, Journal of Integrated Plant Biology (2015) DOI: $10.1111 /$ jipb.12380.

[13] K. Yamaguchi-Shinozaki, K. Shinozaki, Transcriptional regulatory networks in cellular responses and tolerance to dehydration and cold stresses, Ann Rev Plant Biol. 57 (2006) 781-803.

[14] R. Katam, J. Saurez, S. Williams, F. Matta, V. Gottschalk, Proc. Fla. State Hort. Soc., 126 (2013) 8-13.

[15] K. Katam, K.A. Jones, K. Sakata, Advances in proteomics and bioinformatics in agriculture research and crop improvement, J. Proteomics Bioinform., 8 (2015) 39-48.

[16] G.H. Salekeh, H.J. Siopongco, I.J. Wade, B. Ghareyazie, J. Bennett, A proteomics 
analysis of rice leaves during drought stress and recovery, Proteomics 2 (2002) 11311145.

[17] F.M. Abbasi, S. Komatsu, A proteomic approach to analyze salt-responsive proteins in rice leaf sheath, Proteomics, 4 (2004) 2072-2081.

[18] M. Hajhaeidri, M. Abdollahian-Noghabi, H. Askari, M. Heidari, S.Y. Sadeghian, E.S. Ober, G.S. Salekdeh, Proteome analysis of sugar beet leaves under drought stress, Proteomics 5 (2005) 950-960.

[19] R. Katam, V. Gottschalk, P. Survajahala, G. Brewster, P. Payton, K. Sakata, L.M. Latinwo, Advances in Proteomics Research in Peanut Genetics and Breeding In: in: N. Mallikarjun and R. Varshney (Eds.), Genetics, Genomics ad Breeding of Peanuts, CRC Press, Science Publishers, Boca Raton, (2014) 161-177.

[20] V. Kandula, R. Anupalli, P. Amareshwari, R. Katam, Applications of bioinformatics tools to genetic mapping and diversity in peanut, in: N. Mallikarjun and R. Varshney (Eds.), Genetics, Genomics ad Breeding of Peanuts, CRC Press, Science Publishers, Boca Raton, 2014, pp. 216-231.

[21] V. Kandula, V. Gottschalk, R. Katam, R. Anupalli, Peanut Bioinformatics: Tools and applications for developing more effective immunotherapies for peanut allergy and improving food safety, in: P.B. Kavi Kishor, R. Bandopadhyay, P. Suravajhala (Eds.) Agricultural Bioinformatics, Springer, New Delhi, 2014, pp. 129-137.

[22] R. Katam, S.M. Basha, C. Parks, K. Sakata, L.M. Latinwo, Identification and characterization of differentially expressed leaf proteins among Vitis species, Annals of Applied Biology, 160 (2012) 273-290.

[23] R Rakwal, G.K. Agrawal, M. Yonekura, Separation of proteins from stressed rice 
(Oryza sativa L.) leaf tissues by two dimensional polyacrylamide gel electrophoresis: induction of pathogenesis-related and cellular protectant proteins by jasmonic acid UV irradiation and copper chloride, Electrophoresis 20 (1999) 147-154.

[24] S. Srivastava, B. Fristensky, N.N.V. Kav, Constitutive expression of a PR10 protein enhances the germination of Brassica napus under saline conditions, Plant Cell Physiol. 1320 (2004) 1324-1345.

[25] Hajduch M, Casteel JE, Hurrelmeyer KE, Song Z, Agrawal GK, Thelen JJ Proteomic analysis of seed filling in Brassica napus. Developmental characterization of metabolic isozymes using high-resolution two-dimensional gel electrophoresis, Plant Physiol., 141 (2006) 32-46.

[26] D. Vincent, A. Ergul, M.C. Bohlman, E.A.R.Tattersall, R.L.Tillett, M.D. Wheatley, R. Woolsey, D.R. Quilici, J. Joets, K. Schlauch, D.A. Schooley, J.C. Cushman, G.R. Cramer, Proteomic analysis reveals differences between Vitis vinifera L. cv. Chardonnay and cv. Cabernet Sauvignon and their responses to water deficit and salinity, J Exp Bot. 58 (2007) 1873-1892.

[27] D. Bhushan, A. Pandey, M.K. Choudhary, A. Datta, S. Chakraborty, N. Chakraborty, Comparative proteomics analysis of differentially expressed proteins in chickpea extracellular matrix during dehydration stress, Mol Cell Proteomics 6 (2007) 1868-1884.

[28] S.M. Basha, R. Katam, K.S.S. Naik, Differential response of peanut genotypes to water stress, Peanut Science, 34 (2007) 96-104.

[29] R. Katam, H.K.N. Vasanthaiah, S.M. Basha, Proteomic approach to screen peanut genotypes with enhanced nutritional qualities, In Frontiers in the Convergence of 
Bioscience and Information Technologies, FBIT, Korea 2007, 171-178.

[30] X.Q. Liang, M. Luo, C.C. Holbrook, B.Z. Guo, Storage protein profiles in Spanish and runner market type peanuts and potential markers, BMC Plant Biol. 6 (2006) 24.

[31] K.R. Kottapalli, P. Payton, R. Rakwal, G.K. Agrawal, J. Shibato, M. Burow, N. Puppala, Proteomics analysis of mature seed of four peanut cultivars using twodimensional gel electrophoresis reveals distinct differential expression of storage, antinutritional, and allergenic proteins, Plant Sci. 174 (2008) 321-329.

[32] K.R. Kottapalli, R. Rakwal, J. Shibato, G. Burow, D. Tissue, J. Burke, N. Puppala, M. Burow, P. Payton, Physiology and proteomics of the water-deficit stress response in three contrasting peanut genotypes, Plant Cell Environ. 32 (2008) 380-407.

[33] N. Tanaka, S. Mitsui, H. Nobori, K. Yanagi, S. Komatsu, Expression and function of proteins during development of the basal region in rice seedlings, Mol Cell Proteomics 4 (2005) 796-808.

[34] A. Hasiguchi, K. Sakata, S. Komatsu, Proteome analysis of early-stage soybean seedlings under flooding stress, J Proteome Res. 4 (2009) 2058-2069.

[35] R. Katam, S.M. Basha, H.K.N. Vasanthaiah, K.S.S. Naik, Identification of drought tolerant groundnut genotypes employing proteomics approach. J SAT Agri. Res., 5 (2007) 1-4.

[36] R. Katam, S.M. Basha, P. Suravajhala, T. Pechan, Analysis of peanut leaf proteome, J Proteome Res. 9 (2010) 2236-2254.

[37] V. Chandrika, P. Parameswari, G. Sreenivas, Effect of sowing time and rainfall distribution on yield of rain fed groundnut (Arachis hypogea L.) in southern agro-climatic zone of Andhra Pradesh, Legume Res. 31 (2008) 54-56. 
[38] A.J. Norden, R.W. Lipscomb, W.A. Carver, Registration of Florunner peanuts (Reg. No. 2, Crop Sci. 9 (1969) 850.

[39] A. Izanloo, A.G. Condon, P. Langridge, M. Tester, T. Schnurbusch, Different mechanisms of adaptation to cyclic water stress in two south Australian bread wheat cultivars, J Exp Bot. 59 (2008) 3327-3346.

[40] J.J. Irigoyen, W. Emerich, M. Sanchez-Diaz, Water stress induced changes in concentrations of proline and total soluble sugars in nodulated alfalfa (Medicago sativa) plants, Physiol. Plantarum 84 (1992) 5-60.

[41] Y. Nakano, K. Asada, Hydrogen peroxide is scavenged by ascorbate-specific peroxide in spinach chloroplasts, Plant Cell Physiol. 22 (1981) 867-880.

[42] M. Bradford, A rapid and sensitive method for the quantification of microgram quantities of protein utilizing the principle of protein-dye binding, Anal Biochem., 72 (1976) 248-254.

[43] S. Mujahid, T. Pechan, C. Wang, Improved solubilization of surface proteins from Listeria monocytogenes for 2-DE, Electrophoresis, 28 (2007) 3998-4007.

[44] D.N. Perkins, D.J. Pappin, D.M. Creasy, J.S. Cottrell, Probability-based protein identification by searching sequence databases using mass spectrometry data, Electrophoresis 20 (1999) 3551-3567.

[45] S. Gotz, J.M. Garcia-Gomez, J. Terol, T.M. Williams, M.J. Nueda, M. Robles, M. Talon, J. Dopazo, A. Conesa, High-throughput functional annotation and data mining with the Blast2Go suite, Nucleic Acids Res. 36 (2008) 3420-3435.

[45] O. Emanuelsson, B. Soren, V.H. Gunnar, N. Henrik, Locating proteins in the cell using Target P, Signal P, and related tools, Nature Protocols 2 (2007) 953-971. 
[46] S. Mitsui, K. Sakata, H. Nobori, S. Komatsu, A novel metric embedding optimal normalization mechanism for clustering of series data, IEICE Transactions on Information and Systems E91-D 9 (2008) 2369-2371.

[47] C. Jian, L. Peng, L. Guang, X. Feng, Z. Chen, L. Yuhua, Y. Zhongnan, W. Guang, Y. Qingbo, L. Yixue, S. Tieliu, AtPID: Arabidopsis thaliana protein interactome database an integrative platform for plant systems biology, Nucleic Acids Res. 36 (2008) D999D1008.

[48] H.K.N. Vasanthaiah, R. Katam, S.M. Basha, Efficient protocol for isolation of functional RNA from different grape tissue rich in polyphenols and polysaccharides for gene expression studies, Electronic J. Biotechnology 11(2008).

[49] A. Untergasser, I. Cutcutache, T. Koressaar, J. Ye, B.C. Faircloth, M. Remm, S.G. Rozen, Primer3-New capabilities and interfaces, Nucleic Acids Research 40 (2012) e115. [50] L. Su, L. Cao, R. Zhou, Z. Jiang, K. Xiao, W. Kong, H. Wang, J. Deng, B. Wen, F. Tan, Y. Zhang, L. Xie (2013). Identification of novel biomarkers for sepsis prognosis via urinary proteomic analysis using iTRAQ labeling and 2D-LC-MS/MS. PLoS One 8(1): e54237.

[51] G.J. Hamlyn, Monitoring plant and soil water status: Established and novel methods revisited and their relevance to studies of drought tolerance, J Exp Bot. 58 (2007) 119130.

[52] P. Valentovic, M. Luxova, L. Kolarovic, O. Gasparikova, Effect of osmotic stress on compatible solutes content, membrane stability and water relations in two maize cultivars, Plant Soil Environ 52 (2006) 186-191.

[53] Y. Onda, Y. Kobori, Differential activity of rice protein disulfide isomerase family 
members for disulfide bond formation and reduction, FEBS Open Bio., (2014) 730-734.

[54] A.M. Timpeio, M.G. Ggidi, L. Zolla, Proteomics applied on plant abiotic stresses: Role of heat shock proteins (HSP), J Proteomics 71 (2008) 391-411.

[55] P.G. Romano, P. Horton, J.E. Gray, The Arabidopsis cyclophilin gene family, Plant Physiol. 134 (2004) 1268-1282.

[56] P. Lund, The chaperonin cycle and protein folding, BioEssays 16 (2005) 229-231.

[57] A. Malki, T. Caldas, A. Parmeggiani, M. Kohiyama, G. Richarmea, Specificity of elongation factor EF-TU for hydrophobic peptidesq, Biochem Bioph Res. Co 296 (2002) $749-754$.

[58] S. Rinalducci, M.G. Egidi, G. Karimzadeh, F.R. Jazii, L. Zolla, Proteomic analysis of a spring wheat cultivar in response to prolonged cold stress, Electrophoresis 32 (2011) $1807-1818$.

[59] M.M. Bazargani, E. Sarhadi, A.A. Shahnejat Bushehri, A. Matros, H.P. Mock, M.R. Naghavi, V. Hajihoseini, M. Mardi, M.R. Hajirezaei, F. Moradi, B. Ehdaie, G.H. Salekdeh, A proteomics view on the role of drought-induced senescence and oxidative stress defense in enhanced stem reserves remobilization in wheat, Journal of Proteomics 74 (2011) 1959-1973.

[60] M.A.J. Parry, P.J. Andralojc, V. Khan, P.J. Lea, A.J. Keys, RuBisCO activity: effects of drought stress, Ann Bot. 89 (2002) 833-839.

[61] L. Xiong, J.K. Zhu, Molecular and genetic aspects of plant responses to osmotic stress, Plant Cell Environ., 25 (2002) 131-140.

[62] A. Marmagne, M.A. Rouet, M. Ferro, N. Rolland, J. Joyard, J. Garin, H. BarbierBrygoo, G. Ephritikhine, Identification of new intrinsic proteins in Arabidopsis plasma 
membrane proteome, Mol Cell Proteomics 3 (2004) 675-691.

[63] X.Y. Jia, Y.X. Chong, J. Rui-Lian, L. Run-Zhi, M. Xin-Guo, W. Ji-Ping, C. XiaoPing, Molecular cloning and characterization of wheat calreticulin (CRT) gene involved in drought-stressed responses, J Exp Bot. 59 (2008) 739-751.

[64] R.W. Padgett, Intracellular signaling: fleshing out the TGF $\beta$ pathway, Current Biol. 9 (1991) R408-R411.

[65] J. Grimplet, M.D. Wheatley, H.B. Jouira, L.G. Deluc, G.R. Cramer, J.C. Cushman, Proteomic and selected metabolite analysis of grape berry tissues under well watered and water-deficit stress conditions, Proteomics 9 (2009) 2503-2528.

[66] S. Ravanel, M.A. Block, P. Rippert, S. Jabrin, G. Curien, F. Reeille, R. Douce, Methionine metabolism in plants: chloroplasts are autonomous for de novo methionine synthesis and can import S-adenosylmethionine from the cytosol, J Biol Chem. 279 (2004) 22548-22557.

[67] S. Zchut, M. Weiss, U. Pick, Temperature regulated expression of a glycine rich RNA binding protein in the halotolerant alga Dunalielia salina, J Plant Physiol. 160 (2003) 1375-1384.

[68] G.R. Cramer, S.C. Van Sluyter, D.Hopper, D. Pascovici, T. Keighley, P.A. Haynes, Proteomics analysis indicates massive changes in metabolism prior to the inhibition of growth and photosynthesis of grapevine (Vitis vinifera L.) in response to water deficit, BMC Plant Biology, 13 (2011), 49.

[69] J.T. van Dongen, K.J. Gupta, S.J. Ramirez-Aguilar, W.L. Araujo, A. Nunes-Nesi, A.R. Fernie, Regulation of respiration in plants: a role for alternative metabolic pathways. J Plant Physiol. 168 (2011) 1434-1443. 
[70] M. Khozaei, S. Fisk, T. Lawson, Y. Gibon, R. Sulpice, M. Stitt, S.C. Lefebvre, C.A. Rainesa, Overexpression of plastid transketolase in tobacco results in a thiamine auxotrophic phenotype, Plant cell, (2015) 432-447.

[71] A. Ambrosone, G. Batelli, R. Nurcato, V. Aurilia, P. Punzo, D.K. Bangarusamy et. Al., The Arabidopsis RNA-binding protein in AtRGGA regulates tolerance to salt and frought stress, Plant Physiology, (2015) 292-306.

[72] G. Tzivion, J. Avruch, 14-3-3 proteins: active cofactors in cellular regulation by serine/threonine phosphorylation, J Bio Chem. 277 (2002) 3061-3064.

[73] A.H. Christie, G.G. Allen, J.T. Gregory, Induction of vacuolar ATPase and mitochondrial ATP synthase by aluminum in an aluminum-resistant cultivar of wheat, Plant Physiol. 125 (2001) 2068-2077.

[74] X. Jiang, E.O. Leidi, J.M. Pardo, How do vacuolar NHX exchangers function in plant salt tolerance? Plant Signal Behav. 5 (2010) 792-795.

[75] X. Chen, Y. Wang, J. Li, A. Jiang, Y. Cheng, W. Zhang, Mitochondrial proteome during salt stress-induced programmed cell death in rice, Plant Physiology and Biochemistry 47 (2009) 407-415

[76] V. Castro-Rodríguez, A. Garcia-Gutierrez, R.A. Canas, M. Pascual, C. Avila, F.M. Canovas, Redundancy and metabolic function of the glutamine synthetase gene family in poplar, BMC Plant Biology 15 (2015) 1.

[77] Y. Takenaka, S. Nakano, M. Tamoi, S. Sakuda, T. Fukamizo, Chitinase gene expression in response to environmental stresses in Arabidopsis thaliana: Chitinase inhibitor allosamidin enhances stress tolerance, Biosci. Biotechnol. Biochem., 73 (2009) 1066-1071. 
[78] K. S'niegowska-S'wierk, E.Dubas, M. Rapacz, Drought-induced changes in the actin cytoskeleton of barley (Hordeum vulgare L.) leaves, Acta Physiol Plant 37 (2015) 73.

[79] I. Farkas, V. Dombradi, M. Miskei, L. Szabados, C. Koncz, Arabidopsis PPP family of serine/threonine phosphatases, Trends Plant Sci., 12 (2007) 169-176.

[80] T. Tabuchi, Y. Kawaguchi, T. Azuma, T. Nanmori, T. Yasuda, Similar regulation patterns of choline monooxygenase, phosphoethanolamine n-methyltransferase and sadenosyl-1-methionine synthetase in leaves of the halophyte Atriplex nummularia L., Plant Cell Physiol. 46 (2005) 505-513.

[81] J. Chittoor, J. Leach, F. White, Differential induction of a peroxidase gene family during infection of rice by Xanthomonas oryzae pv. Oryzae, Mol. Plant Microbe, 10 (1997) 861-871.

[82] R.S. McKibbin, N. Muttucumar, M.J. Paul, S.J. Powers, M.M. Burrell, S. Coates, P.C. Purcell, A. Tiessen, P. Geigenberger, N.G. Halford, Production of high-starch, lowglucose potatoes through over-expression of the metabolic regulator SnRK1, Plant Biotech. J. 4 (2006) 409-418.

[83] P. Suravajhala, V.S. Sundarrajan, A classification-scoring schema to validate protein interactors, Bioinformation 8 (2012) 34-39.

[84] D.K. Hincha, M. Hagemann, Stabilization of model membranes during drying by compatible solutes involved in the stress tolerance of plants and microorganisms, Biochem J. 383 (2004) 277-283.

[85] M.C. Mathews, C.B. Summers, G.W. Felton, Ascorbate peroxidase: A novel antioxidant enzyme in insects, Arch Insect Biochem., 34 (1997) 57-68. 


\section{Table Legends:}

Table 1: Reproducibility of two-dimensional electrophoresis gels

Table 2: Identification of water stress responsive proteins in peanut leaf

Table 3: Orthologous proteins showing potential interactors in Arabidopsis thaliana

\section{Figure Legends:}

Figure 1: Effect of dehydration on Water status, Cell membrane stability, Photosynthetic efficiency, and Total sugar contents. 50-day old peanut cultivars Vemana and Florunner were used for comparative estimation of (A) relative water content, (B) electrolyte leakage, (C) photosynthetic efficiency and, (D) sugar accumulation in a time-dependent manner under water stress. All experiments were done in triplicates, and average mean values were plotted against time with standard deviation.

Figure 2: Effect of water stress on leaf protein composition of drought-tolerant (DT) and -susceptible (DS) peanut cultivars. Circles indicate unique protein spots to DT and while inverted triangle indicate unique protein spots in DS cultivars. Triangle indicates newly induced proteins in DT cultivar following 15-day stress.

Figure 3: Principal Component Analysis (PCA) plot of proteins from drought tolerant (DT) and -susceptible (DS) cultivars. PCA is based on the 96 spot features exhibiting statistically significant (ANOVA $\mathrm{p}<0.01)$ changes in abundance in all gel images. Variation of $91.33 \%$ and $85.39 \%$ were observed in PC1 of DT and DS cultivars.

Figure 4: Gene ontology classification of water stress responsive proteins according to their (A) biological function and, (B) location in the cell categories as per the annotation in the Viridiplantae taxonomic databases. 
Figure 5: Protein profiles of functional groups during water stress. Heat map of the $\log 2$ relative abundance of proteins through the stress was created using Genesis v1.0 [86] with the MS/MS quantitative data. For each protein, the sequence description assigned with BLAST2GO is provided. Proteins are grouped according to their function. Each block represents time course (from left to right; control, Stress-1 (3-d), Stress-2 (7-d) and, Stress-3 (15-d). Blocks in grey indicate absence of the corresponding protein.

Figure 6: Hierarchical cluster depicting the expression profile of water stress responsive (WSR) proteins in DT and DS cultivars. (A): The temporally changed profiles of 96 WSR proteins were divided into 5 clusters in both DT and DS. Expression profile in tree algorithm cluster for individual proteins are indicated in gray lines, while the median expression profile is marked in red for each cluster. The interval of tics in the vertical axis corresponds to a ten-fold change. The number of proteins in each cluster $(\mathrm{N})$ is given in the left lower corner with the cluster name. The area of a circle is proportional to the number of proteins. The clusters with $n>x$, were taken into consideration for the study of co-expression patterns for functionally similar proteins. (B): Algorithm cluster tree shown by a heat map based on a fold induction against control data of each protein. Stress 1, 2 and 3 indicates a fold induction after 3, 7, and 15day after initiating water stress, respectively. Functional classification is denoted by colored cell. Colored line in the middle of the figure connects same proteins in DT and DS cultivar for major proteins.

Figure 7: Protein interactions in DT and DS cultivars. Functional group of each protein is indicated in different colors. A: Protein interactions in DT peanut showing more interactions compared to DS (B). The number of interacting proteins involved in various biological functions is shown in C. More proteins involved in protein synthesis and 
metabolism are associated with interactions in DT cultivar than DS. D. Formula used to determine the interaction of proteins. The estimated interactions were evaluated based on a goodness-of-fit calculated from "multiple-correlation coefficient" (R) between an expression profile and simulated profile of a protein positioned on the downstream side of an interaction. Significant interactions of individual proteins were indicated based on the first deciles (top 10\%) of multiple co-relation co-efficient R. For each protein, we calculated the average of the $\mathrm{R}$ corresponding to the interactions that the protein regulated the expression of the other proteins and determine the intensity of their interactions between the proteins, Where: $\mathrm{x}_{\mathrm{i}}$ : $\mathrm{i}^{\text {th }}$ protein expression; $\mathrm{i}: \mathrm{i}^{\text {th }}$ protein production velocity coefficient; $\mathrm{g}_{\mathrm{ij}}$ : coefficient of $\mathrm{i}^{\text {th }}$ protein production velocity and $\mathrm{j}^{\text {th }}$ protein expression; $i$ : $i^{\text {th }}$ protein degradation velocity coefficient; $h_{i j}$ : coefficient of $i^{\text {th }}$ protein degradation velocity and $\mathrm{j}^{\text {th }}$ protein expression.

Figure 8: Effects of water stress on expression levels of key genes in peanut leaf. Relative mRNA abundances were normalized against actin gene abundance. Stress 1: 3 days, Stress 2: 7 days, and Stress 3: 15 days water withholding respectively. RT-qPCR was performed on Bio-Rad iCycler using the cDNA product corresponding to $20 \mathrm{ng}$ of total RNA in a $20 \mu \mathrm{l}$ reaction mixture, that includes $1 \mu \mathrm{L}$ of forward and reverse primers of the transcripts, for selected genes using SYBR green method. PCR conditions were: $95^{\circ} \mathrm{C}$ for $30 \mathrm{~s}$, then 45 cycles of $95^{\circ} \mathrm{C}$ for $10 \mathrm{~s}$ and $60^{\circ} \mathrm{C}$ for $30 \mathrm{~s}$. Data was acquired at $60^{\circ} \mathrm{C}$. Data was normalized using the Actin gene $\mathrm{Ct}$ value, and extent of change was calculated using the $\mathrm{Ct}$ value of the calibrator (control samples -no water stress treatment) using the formula $2^{-\Delta \Delta C t}$. 
Figure 9: Enzymatic activities of ascorbate peroxidase (APX) under water stress. APX activity is measured in terms of fold change over the three time points.

Figure 10: Model depicting pathways putatively functional in two distinct peanut cultivars under water stress conferring drought tolerance. Proteins identified in this study are indicated in boxes and displayed on the corresponding metabolic pathways. The abundance level of individual proteins is shown in box with colors. ACT12-Actin; Act Iso B-Actin isoform B; APX-aspartate peroxidase; $\mathrm{CH} 21 / \mathrm{CPN}$ 60-chaperones; $\mathrm{CMO}$ Choline-choline monooxygenase; CYP-cyclophilin; DS-Drought susceptible; DTDrought tolerant; FBA2-Fructose bisphosphate aldolase; OSGRP2-Glycine rich proteins; Mtr-Methionine synthase; PER43-Peroxidase 43; SOD-Superoxide dismutase; SAM-Sadenosyl-L-methionine; PP1-Serine/threonine kinase; TKT3-Transketolase. The numbers next to the boxes corresponding to the protein spots resolved in 2-DE gel. 


\section{Table 1: Reproducibility of two-dimensional gels}

\begin{tabular}{|c|c|c|}
\hline \multirow{2}{*}{$\begin{array}{l}\text { Leaf tissue harvest time } \\
\text { and stress treatment }\end{array}$} & \multicolumn{2}{|c|}{ Average number of high quality protein spots visualized on 2-DE gel } \\
\hline & Drought Tolerant (Vemana) & Drought Susceptible (Florunner) \\
\hline Control & 300 & 298 \\
\hline 3 day stress & 297 & 290 \\
\hline 7 day stress & 306 & 283 \\
\hline 15 day stress & 304 & 273 \\
\hline
\end{tabular}

Average number of spots in 3 replicate gels

Spots having quality score as assigned by PD Quest version 8.2.1 
Table 2: Identification of water stress responsive proteins in peanut leaf

\begin{tabular}{|c|c|c|c|c|c|c|c|c|c|}
\hline $\begin{array}{l}\text { Spot } \\
\text { no. }^{a}\end{array}$ & Homologous protein & $\begin{array}{c}\text { Fold } \\
\text { change }^{b} \text { in } \\
\text { Drought } \\
\text { Tolerant }\end{array}$ & $\begin{array}{c}\text { Fold } \\
\text { change }{ }^{\mathrm{b}} \text { in } \\
\text { Drought } \\
\text { Susceptible }\end{array}$ & Reference Organism & $\begin{array}{l}\text { Accession } \\
\text { number }^{c}\end{array}$ & $\begin{array}{c}\operatorname{Mr}(D a) \\
\operatorname{Theo}^{d} / \\
\operatorname{Exp}^{\text {e }}\end{array}$ & $\begin{array}{c}\text { pI-Theo }^{\text {d }} \\
\operatorname{Exp}^{\mathrm{e}}\end{array}$ & $\begin{array}{l}\text { Peptide } \\
\text { count }\end{array}$ & $\begin{array}{l}\text { Protein } \\
\text { score }^{\mathrm{g}}\end{array}$ \\
\hline 7 & $\begin{array}{l}\text { Protein Synthesis / Modification } \\
\text { Heat shock protein, 70K, chloroplast } \\
\text { (HSP70) }\end{array}$ & 3.23 & 0.5 & Cucumis sativus & $\mathrm{T} 10248$ & $\begin{array}{c}71171 / \\
58099\end{array}$ & $5.17 / 4.6$ & 18 & 736 \\
\hline $8^{*}$ & $\begin{array}{l}\text { Heat shock protein, } 70 \mathrm{~K} \text {, chloroplast } \\
\text { (HSP70) }\end{array}$ & 1.97 & Not found & Cucumis sativus & T10248 & $\begin{array}{l}75366 / \\
59769\end{array}$ & $5.15 / 5.2$ & 18 & 736 \\
\hline 9 & $\begin{array}{l}\text { Chaperonin } 60 \text { alpha chain } \\
\text { precursor, chloroplast }(\mathrm{CH} 60)\end{array}$ & 2.54 & 0.57 & Brassica napa & S38642 & $\begin{array}{l}62945 / \\
49087\end{array}$ & $5.85 / 4.5$ & 11 & 210 \\
\hline $11^{\#}$ & $\begin{array}{l}\text { Protein disulfide-isomerase } 2 \\
\text { (PDI2) }\end{array}$ & 2.09 & 0.42 & Oryza sativa & NP_177875.1 & NA & NA & NA & NA \\
\hline $13 *$ & $\begin{array}{l}\text { Chaperonin } 60 \text { alpha chain } \\
\text { precursor, chloroplast }(\mathrm{CH} 60)\end{array}$ & 1.93 & 0.72 & Pisum sativum & T06518 & $\begin{array}{l}61941 / \\
42398\end{array}$ & $5.15 / 5.4$ & 10 & 210 \\
\hline 14 & $\begin{array}{l}\text { Chaperonin } 60 \text { subunt beta } 1 \text {, } \\
\text { chloroplastic }(\mathrm{CH} 60)\end{array}$ & 1.50 & 0.39 & Arabidopsis thaliana & Q9FHA9 & $\begin{array}{l}63118 / \\
42398\end{array}$ & $5.73 / 5.5$ & 10 & 95 \\
\hline 15 & $\begin{array}{l}\text { Probable chaperonin } 60 \text { beta chain- } \\
\text { chloroplast }(\mathrm{CH} 60)\end{array}$ & 1.5 & 0.46 & Pisum sativum & T06412 & $\begin{array}{l}62945 / \\
55153\end{array}$ & $5.85 / 5.2$ & 16 & 362 \\
\hline 32 & Elongation factor 1-beta (EF1) & 2.33 & 0.2 & Oryza sativa & EF1B_ORYSA & $\begin{array}{l}24716 / \\
33452\end{array}$ & $4.36 / 4.8$ & 4 & 77 \\
\hline 40 & GrpE protein homolog (GRPE) & 1.98 & 0.11 & Arabidopsis thaliana & Q9XQC7 & $\begin{array}{l}35699 / \\
28978\end{array}$ & $4.57 / 4.1$ & 4 & 134 \\
\hline $59^{\#}$ & Chaperonin $21(\mathrm{CH} 21)$ & 1.74 & 0.65 & $\begin{array}{l}\text { Lycopersicum } \\
\text { esculentum }\end{array}$ & Q9M583 & NA & NA & NA & NA \\
\hline 72 & $\begin{array}{l}\text { Peptidylprolyl isomerase (EC } \\
\text { 5.2.1.8) Cyclophilin (CYP) }\end{array}$ & 1.53 & 0.12 & $\begin{array}{l}\text { Madagascar } \\
\text { periwinkle }\end{array}$ & T10056 & $\begin{array}{l}18273 / \\
17886\end{array}$ & $8.36 / 5.3$ & 2 & 67 \\
\hline
\end{tabular}




\begin{tabular}{|c|c|}
\hline $74^{\#}$ & Chaperonin $21(\mathrm{CH} 21)$ \\
\hline $80 *$ & $\begin{array}{l}\text { Peptidylprolyl isomerase (EC } \\
\text { 5.2.1.8) Cyclophilin (CYP) }\end{array}$ \\
\hline 83 & $\begin{array}{l}\text { 50S ribosomal protein L12- } \\
\text { chloroplastic (RK12) }\end{array}$ \\
\hline 85 & $\begin{array}{l}\text { Peptidylprolyl isomerase (EC } \\
\text { 5.2.1.8) Cyclophilin (CYP) }\end{array}$ \\
\hline $86^{\#}$ & $\begin{array}{l}\text { Peptidylprolyl isomerase (EC } \\
\text { 5.2.1.8) Cyclophilin (CYP) }\end{array}$ \\
\hline 1 & $\begin{array}{l}\text { Photosynthesis } \\
\text { Ribulose 1,5-bisphosphate } \\
\text { carboxylase-oxygenase large } \\
\text { subunit (rbcL) }\end{array}$ \\
\hline 3 & $\begin{array}{l}\text { Ribulose } 1,5 \text {-bisphosphate } \\
\text { carboxylase-oxygenase large } \\
\text { subunit (rbcL) }\end{array}$ \\
\hline 2 & $\begin{array}{l}\text { Sedoheptulose bisphosphatase } \\
\text { (SBPase) }\end{array}$ \\
\hline 22 & $\begin{array}{l}\text { Ribulose 1,5-bisphosphate } \\
\text { carboxylase-oxygenase large } \\
\text { subunit (rbcL) }\end{array}$ \\
\hline $23 *$ & $\begin{array}{l}\text { Ribulose } 1,5 \text {-bisphosphate } \\
\text { carboxylase-oxygenase large } \\
\text { subunit (rbcL) }\end{array}$ \\
\hline 24 & $\begin{array}{l}\text { Ribulose 1,5-bisphosphate } \\
\text { carboxylase (rbcL) }\end{array}$ \\
\hline
\end{tabular}

$\begin{array}{ccllccrr}1.22 & 0.12 & \begin{array}{l}\text { Lycopersicum } \\ \text { esculentum }\end{array} & \text { Q9M583 } & \text { NA } & \text { NA } & \text { NA } & \text { NA } \\ 2.61 & 1.26 & \text { Zea mays } & \text { CSZM } & \begin{array}{c}18337 / \\ 19000\end{array} & 8.91 / 8.9 & 2 & 67 \\ 1.51 & 0.64 & \text { Arabidopsis thaliana } & \text { CAA44226.1 } & \text { NA } & \text { NA } & \text { NA } & \text { NA } \\ 1.07 & 0.49 & \text { Zea maize } & \text { CSZM } & 18337 / & 8.91 / 5.2 & 2 & 67 \\ 3.28 & 0.49 & \text { Zea maize } & \text { CSZM } & \text { NA } & \text { NA } & \text { NA } & \text { NA }\end{array}$

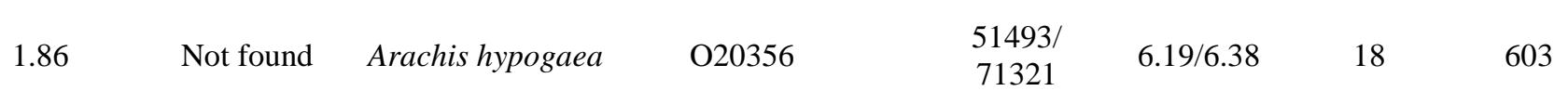

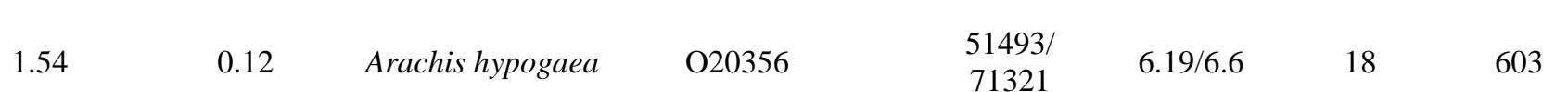

2.14 Not found Arabidopsis thaliana Q940F8 $\quad \begin{array}{rrrr}51666 / & 6.05 / 6.45 & 16 & 423\end{array}$

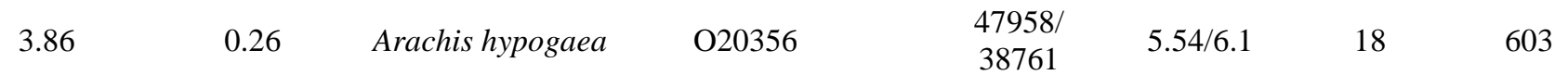

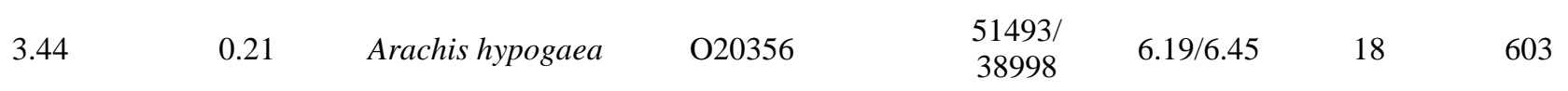

0.35 Justicia odora P28428

51684/

39903

$5.83 / 6.4 \quad 17$

403 
Ribulose 1,5-bisphosphate carboxylase-oxygenase large subunit (rbcL)

\begin{tabular}{|c|c|c|c|c|c|c|c|}
\hline 4.01 & 0.36 & Arachis hypogaea & O20356 & $\begin{array}{c}52036 / \\
39876\end{array}$ & $6.33 / 6.81$ & 18 & 603 \\
\hline 0.50 & 0.37 & Arachis hypogaea & O20356 & $\begin{array}{l}51493 / \\
39865\end{array}$ & $6.19 / 7.12$ & 18 & 603 \\
\hline Not found & Not found & Arachis hypogaea & O20356 & $\begin{array}{l}51493 / \\
41201\end{array}$ & $6.19 / 7.2$ & 18 & 603 \\
\hline 4.28 & 0.23 & Arachis hypogaea & O20356 & $\begin{array}{l}51493 / \\
31832\end{array}$ & $6.19 / 5.1$ & 18 & 603 \\
\hline 1.12 & Not found & $\begin{array}{l}\text { Mesembryanthemum } \\
\text { crystallinum }\end{array}$ & T12436 & $\begin{array}{l}44086 / \\
39875\end{array}$ & $6.03 / 4.9$ & 9 & 325 \\
\hline 1.50 & Not found & Spinacia oleracea & Q8VWP4 & $\begin{array}{l}36662 / \\
38125\end{array}$ & $8.3 / 8.6$ & 11 & 370 \\
\hline 3.19 & Absent & Pisum sativum & S43832 & $\begin{array}{l}36662 / \\
24976\end{array}$ & $8.3 / 8.1$ & 11 & 370 \\
\hline 2.34 & 0.11 & Nicotiana tobaccum & A24430 & $\begin{array}{l}36039 / \\
24535\end{array}$ & $6.0 / 8.8$ & 11 & 370 \\
\hline Absent & Not found & Capsicum аппиит & Q8VWP4 & $\begin{array}{c}33492 / \\
30439\end{array}$ & $6.0 / 8.2$ & 9 & 25 \\
\hline
\end{tabular}

dehydrogenase (NADP)

(phosphorylating) A, chloroplast

(gapA1)

1,5-bisphosphate

carboxylase-oxygenase large

subunit (rbcL)

Ribulose 1,5-bisphosphate

carboxylase-oxygenase large

subunit (rbcL)

Ribulose 1,5-bisphosphate

carboxylase-oxygenase large subunit (rbcL)

Phosphoribulokinase (PRK)

Glyceraldehyde-3-phosphate dehydrogenase (NADP)

(phosphorylating) A, chloroplast

(gapA1)

Glyceraldehyde-3-phosphate

dehydrogenase (NADP)

(phosphorylating) A, chloroplast

gapA1)

Glyceraldehyde-3-phosphate

(phosphorylating) A, chloroplast (gapA1) 
Ribulose 1,5-bisphosphate

Ribulose-bisphosphate carboxylase activase (EC 6.3.4) (RCAB)

2.27

Rubisco activase (RCA)

Sedoheptulose bisphosphatase (EC 3.1.3.37) precursor (SBPase)

Sedoheptulose bisphosphatase (EC 3.1.3.37) precursor (SBPase)

Probable photosystem II stability rotein (HCF136) complex protein 1 precursor (PSBO)

\section{Photosystem II oxygen-evolving} complex protein 1 precursor (PSBO)

Chlorophyll a/b-binding protein precursor (LHCA3)

Ribose-5-phosphate isomerase precursor (EC 5.3.1.6) (SOVF)

Chlorophyll a/b-binding protein precursor (LHCA3) precursor (LHCA3)
5.90

Arabidopsis thaliana

T51828

$$
0.21
$$

Hordeum vulgare

A23703

$0.05 \quad$ Vigna radiata

O98997

0.06

Arabidopsis thaliana

S51838

0.07

Arabidopsis thaliana

Q940F8

$$
0.61 \quad \text { Pisum sativum }
$$

S04132

$0.61 \quad$ Pisum sativum

S04132

0.66

Fagus crenata

O48657

0.66

Spinacia oleracea

Q8RU73

1.04

Fagus crenata

O48657

A29119
0.6
Zea Maize
$47112 /$

32876

$8.62 / 4.55$

10

$47197 /$

32812

$8.62 / 5.2$

10

$7.59 / 4.55$

9

32521

42387

2,342

$6.17 / 5.1 \quad 8$

51493/

$6.19 / 4.74$

25690

44076/

$6.79 / 5.5$

28550

34871/

22768

$6.25 / 4.79$

$34871 /$

22768

$6.25 / 5.3$

$28023 /$

$5.13 / 6.1$

25567

30844/

20982

$6.54 / 4$

28029/

19875

$5.29 / 5.25$

27977/

19540 
$90 *$

91 complex protein 2 (PSPB1)

\section{Defense/ Stress related}

$66^{@} \quad$ Chitinase class II (Chi2)

73

Peroxiredoxin precursor (PRx)

Ascorbate peroxidase (APX)
Absent

Absent

2.88

Absent

1.62

2.34

1.96

2.17

2.49
0.13

Alonsoa meridionalis

Q9M538

0.5

Sorghum bicolor

O81608

0.25

Alonsoa meridionalis

Q9M538

Not found

Phaseolus vulgaris

S20509

0.38

0.99

Arabidopsis thaliana

Q42029

Q42029

Arabidopsis thaliana

28551

Absent Glycine max

Arachis hypogea

S65070

Q9FE12

0.66 Phaseolus vulgaris

Q9SXT2
20814/

18542

$5.17 / 5.3$

20814/

18435

$5.17 / 5.7 \quad 5$

20399/

19654

$4.69 / 5.9$

20814/

18764

$5.17 / 6.3$

$15648 /$

17874

$8.64 / 8.6$

20198/

14100

$9.07 / 4$

$17525 /$

15558

$4.91 / 5$.

$14330 /$

17543

$9.71 / 6.2$

45721/

39054

$5.63 / 5.3$

$28906 /$

24950

28604/

16758

19253/

17835
Signal transduction/ Cellular

biogenesis 
$37 \quad$ Actin (ACT12)

$38^{@ \quad A c t i n ~ i s o f o r m ~ B ~(A C T ~ i s o ~ B) ~}$

Putative brassinosteroid insensitive

$44^{\#} \quad 1$ associated receptor kinase 1 (OsSERK1)

Fibrillin, Homolog to plastid-lipidassociated protein, chromoplast (PAP1)

\section{Metabolism}

Plastid transketolase (TKT3)

Probable glycine dehydrogenase (decarboxylating) (GLDP2)

Methionine synthase (Mtr)

Glutamate-ammonia ligase (GLN2)
1.51

1.52

1.54

1.80

1.95

\section{Not found}

Gossypium hirsutum

Q7XZI9

Absent

Mimosa pudica

T51183

0.54

Oryza sativa

Q8W0B8

0.26

Brassica napus

Q9ZSZ9

$25857 /$

20975

5.12/4.7

$5.37 / 5.4$

13

$5.31 / 5.4$

16

32558

NA

NA

80312/

61246

$6.58 / 6$

113702/

$6.18 / 6.36$

24430/

59123

$5.69 / 6$

29340/

28595

$47733 /$

30759
T14292
Absent Dacus carota
$4.68 / 4.0$

$5.63 / 5.9$
419

NA

13

126

212

82

206

151 
Probable fructose-bisphosphate

4.1.2.13) (FBA2)

Probable fructose-bisphosphate

4.1.2.13) (FBA2)

Probable fructose-bisphosphate

4.1.2.13) (FBA2)

Probable fructose-bisphosphate 4.1.2.13) (FBA2)

Probable fructose-bisphosphate aldolase precursor, chloroplast-(EC 4.1.2.13) (FBA2)

51* Carbonic anhydrase (CAHX)

$52 \quad$ RNA-binding protein (rbp33)

$63 *$

Carbonate dehydratase precursor chloroplast /cytoplasm (CAHX)

Carbonate dehydratase precursor chloroplast/Cytoplasm (CAHX)

64

Putative quinone oxidoreductase (qor)

65* Triosephosphate isomerase (TIM)

69
S29047

38460/

27915

$5.83 / 8.3$

$35462 /$

28500

32926/

24345

35625/

19557

S48675

35625/

19765

21778/

19515

12790/

20532

27256/

22457
Physcomitrella A9SAR2

Q8LR75

\begin{abstract}
$0.11 \quad$ Oryza sativa
\end{abstract}




\begin{tabular}{|c|c|c|c|c|c|c|c|c|c|}
\hline 70 & Carbonic anhydrase (CAHX) & 1.51 & Not found & Nicotiana tabacum & Q9LW91 & $\begin{array}{l}34488 / \\
21035\end{array}$ & $6.41 / 7.6$ & 6 & 200 \\
\hline 71 & Glycine-rich protein (OSGRP2) & 2.96 & 0.53 & Oryza sativa & $\mathrm{O} 22385$ & $\begin{array}{c}16017 / \\
17656\end{array}$ & $7.82 / 4.65$ & 3 & 97 \\
\hline $78^{*}$ & $\begin{array}{l}\text { Putative quinone oxidoreductase } \\
\text { (qor) }\end{array}$ & 4.64 & Not found & Cicer arietinum & Q8L5Q7 & $\begin{array}{c}21708 / \\
18575\end{array}$ & $6.51 / 6.75$ & 2 & 92 \\
\hline $87 *$ & Glycine-rich protein (OSGRP2) & 1.99 & 0.48 & Oryza sativa & $\mathrm{O} 22385$ & $\begin{array}{l}16017 / \\
14534\end{array}$ & $7.82 / 6.23$ & 3 & 97 \\
\hline 89 & Triosephosphate isomerase (TIM) & Absent & Not found & Oryza sativa & Q8LR75 & $\begin{array}{l}27256 / \\
29875\end{array}$ & $5.58 / 8.8$ & 2 & 67 \\
\hline B1 ${ }^{@ \#}$ & $\begin{array}{l}\text { Serine/threonine protein phosphate } \\
\text { PP1 EC (3.1.3.16) (PP1) }\end{array}$ & 27.4 & Absent & Medicago varia & P48488 & NA & NA & NA & NA \\
\hline D5 ${ }^{@ \#}$ & Choline monooxygenase (CMO) & 32.4 & Absent & Arabidopsis thaliana & Q9SZR0 & NA & NA & NA & NA \\
\hline E6 ${ }^{@ \#}$ & Peroxidase 43 (PER43) & 28.6 & Absent & Arabidopsis thaliana & Q9SZH2 & NA & NA & NA & NA \\
\hline \multirow[t]{2}{*}{$\mathrm{H} 1^{@ \#}$} & $\begin{array}{l}\text { SNF } 1 \text { related protein kinase } \\
\text { regulatory subunit beta-2 (KINB1) }\end{array}$ & 13.5 & Absent & Arabidopsis thaliana & Q84VQ1 & NA & NA & NA & NA \\
\hline & Transport & & & & & & & & \\
\hline 10 & $\begin{array}{l}\text { V-type proton ATPase catalytic } \\
\text { subunit A (protein F9K20.5) (VHA- } \\
\text { A) }\end{array}$ & 1.50 & Not found & Arabidopsis thaliana & E96818 & $\begin{array}{l}27374 / \\
48650\end{array}$ & $5.83 / 4.8$ & 14 & 235 \\
\hline $18^{*}$ & $\begin{array}{l}\mathrm{H}+\text { transporting two-sector ATPase } \\
\text { beta chain, mitochondrial (atpB) }\end{array}$ & 1.01 & 0.19 & $\begin{array}{l}\text { Zea maize; } \\
\text { Xanthophyllum sp. } \\
\text { 'Coode } 7760 K^{\prime}\end{array}$ & S11491 & $\begin{array}{l}59066 / \\
33540\end{array}$ & $6.01 / 5.5$ & 19 & 924 \\
\hline 19 & $\begin{array}{l}\mathrm{H}+\text { transporting two-sector ATPase } \\
\text { beta chain, mitochondrial (atpB) }\end{array}$ & 1.09 & 0.24 & $\begin{array}{l}\text { Zea maize; } \\
\text { Xanthophyllum sp. } \\
\text { 'Coode } 7760 K^{\prime}\end{array}$ & Q9MTT8 & $\begin{array}{l}49104 / \\
34550\end{array}$ & $5.25 / 5.4$ & 19 & 924 \\
\hline
\end{tabular}


Zea maize;

$\mathrm{H}+$ transporting two sector ATPase alpha subunit (atpA)

H+-transporting two-sector ATPase gamma chain precursor, chloroplast (ATPC)

a Spot number as given on the 2-D gel image in Figure 2; b: Protein fold change is the mean spot densities in stressed leaf tissue over the Irrigated control; c: Protein identification number as in Uniprot/NCBI Viridiplantae database; \#Proteins identified de novo sequencing; @ Proteins induced to water stress in drought tolerant cultivar; \$Proteins unique to drought tolerant cultivar; dTheor: Theoretical value; e exp: Experimental value; Mr: Molecular weight; pl: Isoelectric point; $\mathbf{g}$ Protein score: Ion score of identified proteins; ${ }^{*}$ Protein identified in more than one spot on 2DE. Not found: Protein spot was not detected in stressed tissue while present in the corresponding control. Absent: Protein is not detected in either control or stressed tissue. All protein identification and characterization were submitted to PRIDE database http://www.ebi.ac.uk/pride/startSearch.do (Experiment accession number 10105). 
Table 3: Orthologous proteins showing potential interactors in Arabidopsis

\begin{tabular}{|c|c|c|c|c|}
\hline $\begin{array}{l}\text { Protein } \\
\text { spot no. }\end{array}$ & $\begin{array}{l}\text { Peanut Query } \\
\text { (Uniprot) }\end{array}$ & Localization & $\begin{array}{c}\text { Putative Genes Mapped to } \\
\text { Arabidopsis }\end{array}$ & $\begin{array}{c}\text { Interactors mapping in Arabidopsis } \\
\text { (Subcellular location is indicated in } \\
\text { paranthesis) }\end{array}$ \\
\hline 82 & Q9SXV0 & Other & COX6B* & $\mathrm{AHK2}^{\mathrm{b}} \quad \mathrm{CYTC}^{\mathrm{f}}{ }^{\mathrm{f}}$ \\
\hline 73 & Q9FE12 & Chloroplast & ATPER1 & $\begin{array}{c}\operatorname{ATPERXQ}^{\mathrm{g}, \mathrm{j}}(\text { Mito); } \\
\text { (ChAS1) }\end{array}$ \\
\hline 59,74 & Q9M583 & Other & BAND7/HIR2* & No interactors found \\
\hline 44 & Q8W0B8 & Chloroplast & ATPERK1 & No interactors found \\
\hline $\begin{array}{l}72,80,85 \\
86\end{array}$ & Q9XQC7 & Chloroplast & GRPE* & No interactors found \\
\hline $57,60,61$ & 048657 & Chloroplast & LHB1B1* & $\mathrm{LHB1B2}^{\mathrm{k}}(\mathrm{Chl}) ; \mathrm{LHCB2}^{\mathrm{g}} \mathbf{3}^{\mathrm{g}}(\mathrm{Chl})$ \\
\hline 64,78 & Q8L5Q7 & Other & FQR1/qor* & Quinone Reductase $^{\mathrm{j}} ;$ ATCBR $^{\mathrm{j}, \mathrm{m}} ; \mathrm{FNR} 2^{\mathrm{j}, \mathrm{m}} ; \mathrm{FNR} 1^{\mathrm{j}, \mathrm{m}}$ \\
\hline 62 & 081608 & Other & LHCB2.3* & $\mathrm{LHB1B1}^{\mathrm{g}} ; \mathrm{LHCB}^{2.2^{\mathrm{k}}} ; \mathrm{LHCB3}^{\mathrm{k}}$ \\
\hline 75 & Q9SXT2 & Signal Peptide & APX1 & $\operatorname{ATHSFA2}^{\mathrm{m}, \mathrm{f}, \mathrm{j}} ; \operatorname{ATTRX3}^{\mathrm{b}} ;$ RHL41 $^{\mathrm{b}}$ \\
\hline 71,87 & $\mathrm{O} 22385$ & Other & CCR2/OSGRp2* & No interactors found \\
\hline
\end{tabular}




\begin{tabular}{|c|c|c|c|c|}
\hline 38 & Q7XZI9 & Other & ACT12/ACT12* & $\begin{array}{c}\text { ACT1, ACT2, ACT3, ACT4,ACT8,ARP2, ATARP4, } \\
\text { ATARP7, Actin, ATM1, AGB1, ACT11 }\end{array}$ \\
\hline 34 & Q9T0N0 & Other & GRF2/GRF2* & $\begin{array}{l}\text { GRF12, GRF10, GRF11,GRF13, GF,14, GRF8, } \\
\text { MAPKKK5, GRF6, GRF7, GRF3, GRF5, GRF9, GF- } \\
\text { chi }\end{array}$ \\
\hline 52 & Q8SMH8 & Chloroplast & RBP31/RBP31* & $\mathrm{CP33}^{\mathrm{g}}(\mathrm{Chl}) ;$ Kelch repeat $^{\mathrm{g}}$ (Not found) \\
\hline $18,19,21$ & Q9MTT8 & Other & ATPB* & No interactors found \\
\hline 54 & Q9ZSZ9 & Other & FIB* & $A B I 2^{b, p}$ \\
\hline 58 & Q8RU73 & Chloroplast & $\begin{array}{l}\text { Ribose 5-phosphate isomerase/ } \\
\text { Ribose 5-phosphate isomerase * }\end{array}$ & No interactors found \\
\hline $77,90,91$ & Q9M538 & Other & LHCA3/LHCA3* & ARR14 ${ }^{b}$ \\
\hline 14 & Q9FHA9 & Chloroplast & $\begin{array}{l}\text { HSP60-3A, chaperonin, CPN-10, } \\
\text { HSP60-2,CPN60A, } \\
\text { CPN60B,EMB3007, EMB1444, } \\
\text { PPP/HSP60* }\end{array}$ & No interactors found \\
\hline 6 & Q9M619 & Other & ATMS1 & $\mathbf{A T M S 2}^{\mathrm{g}, \mathrm{k}} ; \mathbf{A T M S 3}^{\mathrm{k}}$ \\
\hline $\begin{array}{l}23,27 \\
25,36,26 \\
22,1,3\end{array}$ & O20356 & Other & rbcL* & No interactors found \\
\hline 51,70 & Q9XQB0 & Chloroplast & CA1/CipCa1* & $\operatorname{ATTRX3}^{\mathrm{b}, \mathrm{p}}(\mathrm{Chl}) ;$ BCA6 $^{\mathrm{g}, \mathrm{j}}(\mathrm{Chl})$ \\
\hline
\end{tabular}




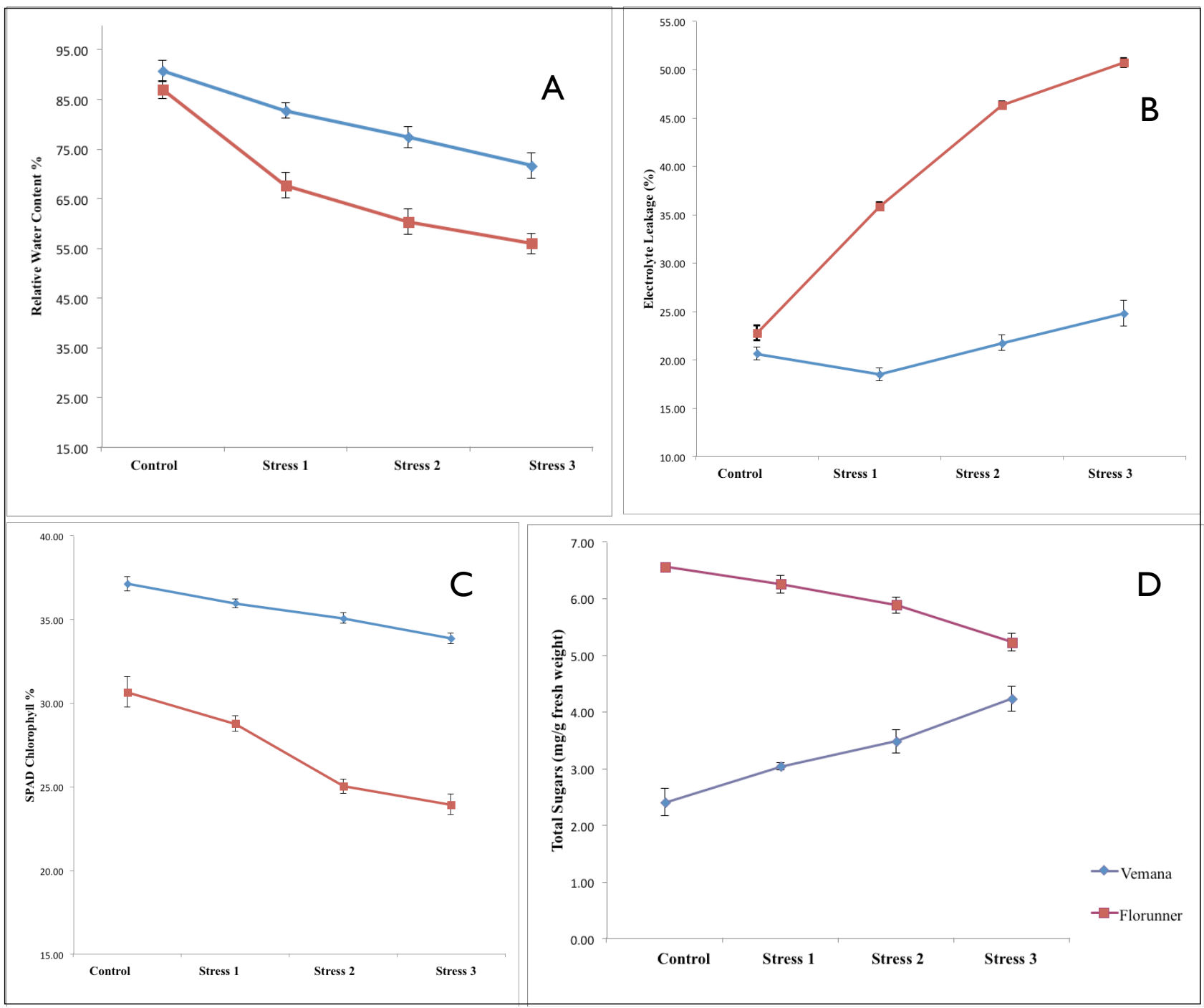

Figure 1: Effect of dehydration on Water status, Cell membrane stability, Photosynthetic efficiency, and Total sugar contents. 50 day old peanut cultivars Vemana and Florunner were used for comparative estimation of RWC (A), electrolyte leakage (B), photosynthetic efficiency (C), sugar accumulation (D) in a time-dependent manner under water stress. All experiments were done in triplicates, and average mean values were plotted against time with standard deviation. 


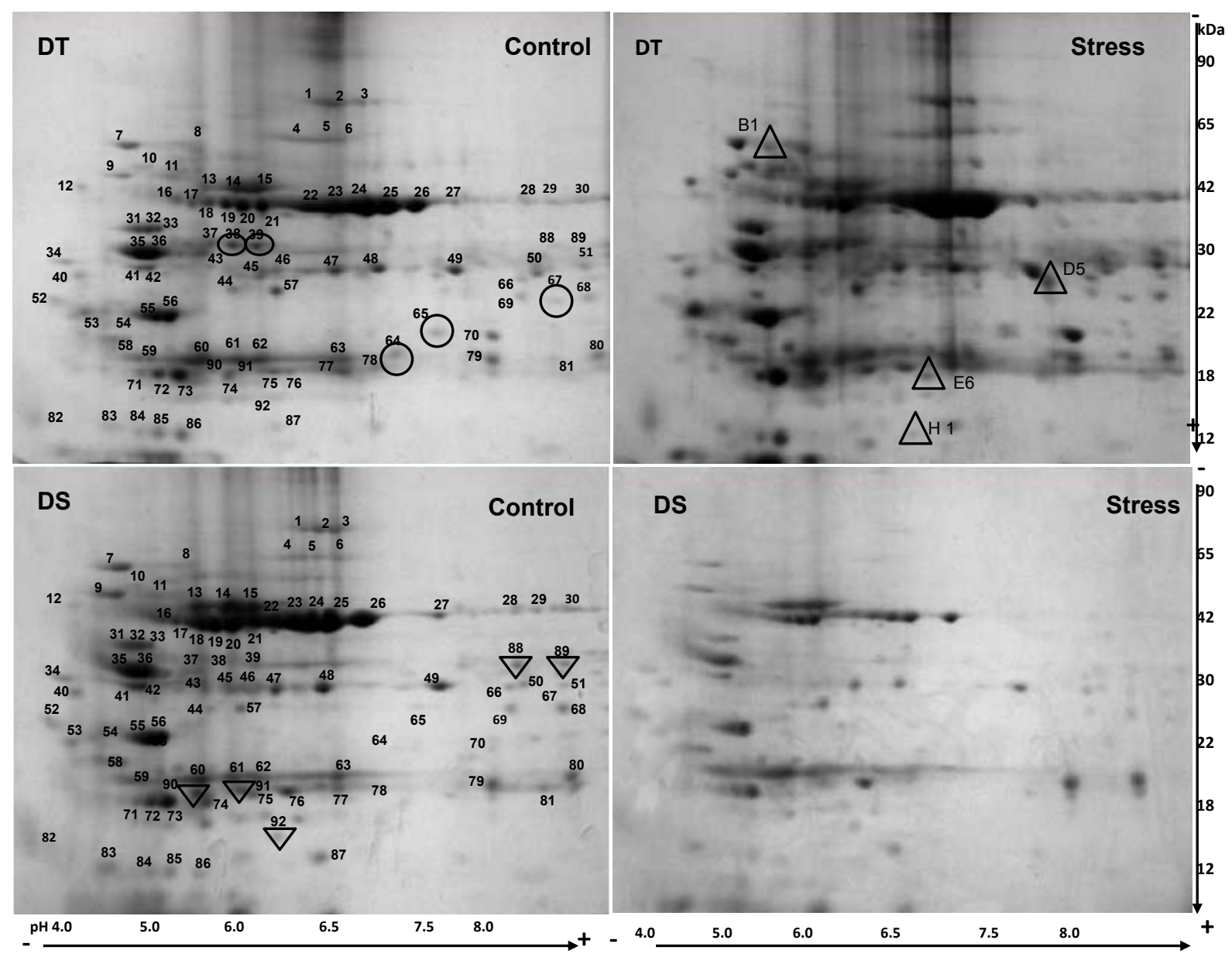

Figure 2: Effect of water stress (WS) on leaf protein composition of drought-tolerant (DT) and susceptible (DS) peanut cultivars. Circles indicate unique protein spots to DT and while inverted triangle indicate unique protein spots in DS cultivars. Triangle indicates newly induced proteins to water stress in DT cultivar following 15 day WS. 
Biplot (axes F1 and F2: $100.00 \%)$

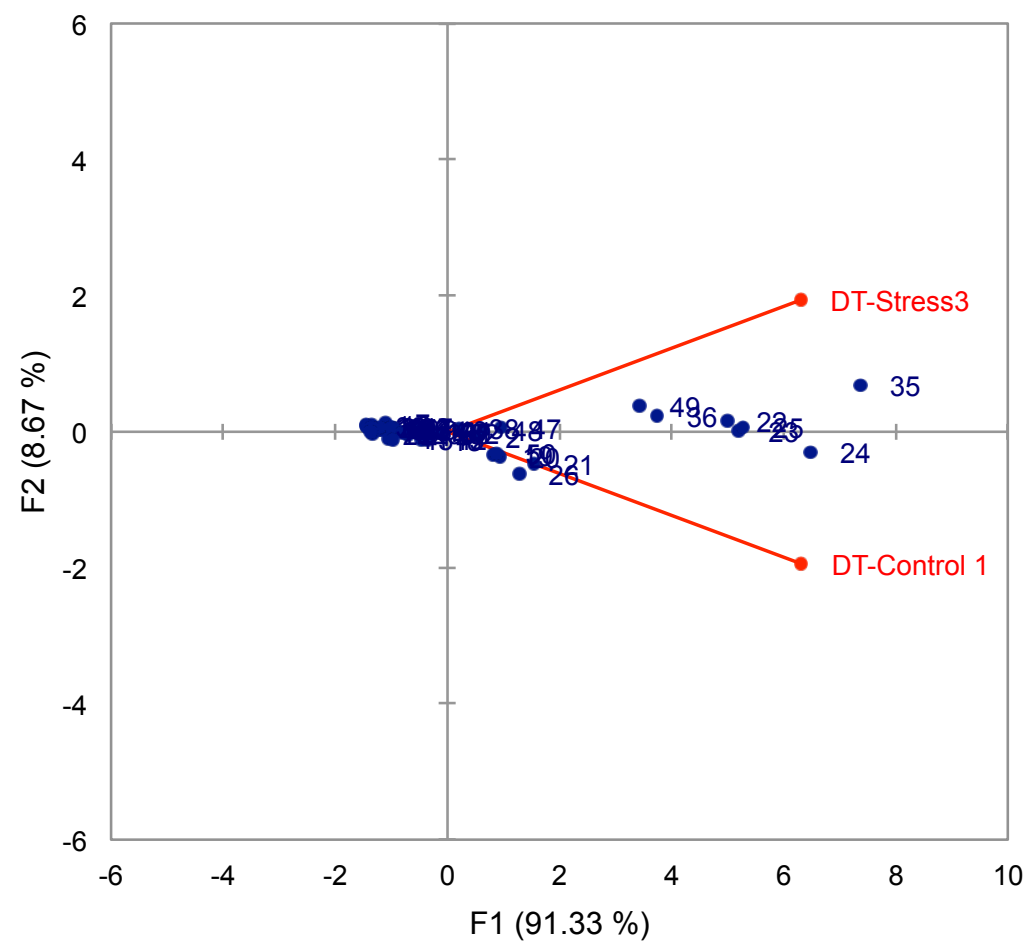

DT: Control vs Stress 3
Biplot (axes F1 and F2: $100.00 \%)$

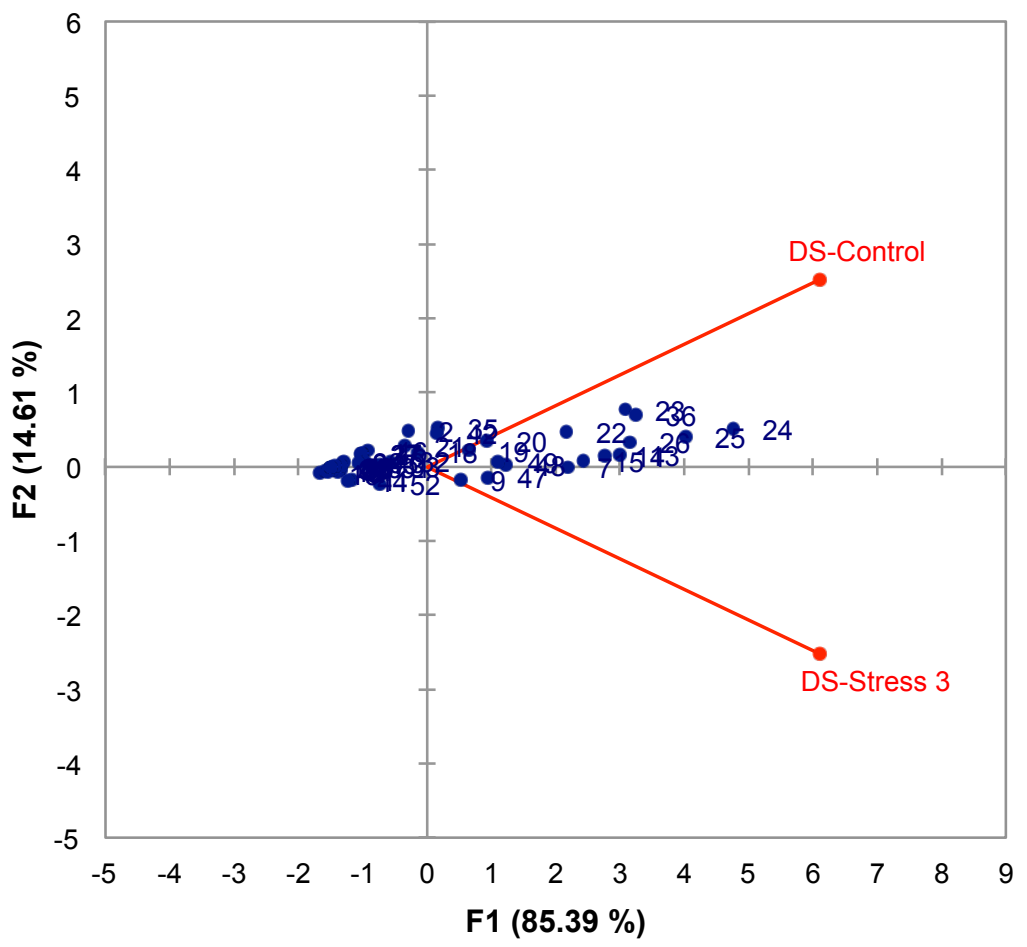

DS: Control vs. Stress 3

Figure 3: PCA score plot of proteins from drought tolerant (DT) and drought susceptible (DS) cultivars. This analysis was based on the 96 spot features exhibiting statistically significant (ANOVA p < 0.01) changes in protein abundance in all gel images. Variation of $91.33 \%$ and $85.39 \%$ were observed in DT and DS cultivars respectively. Water stress was induced by withholding water for 15 days. 
A

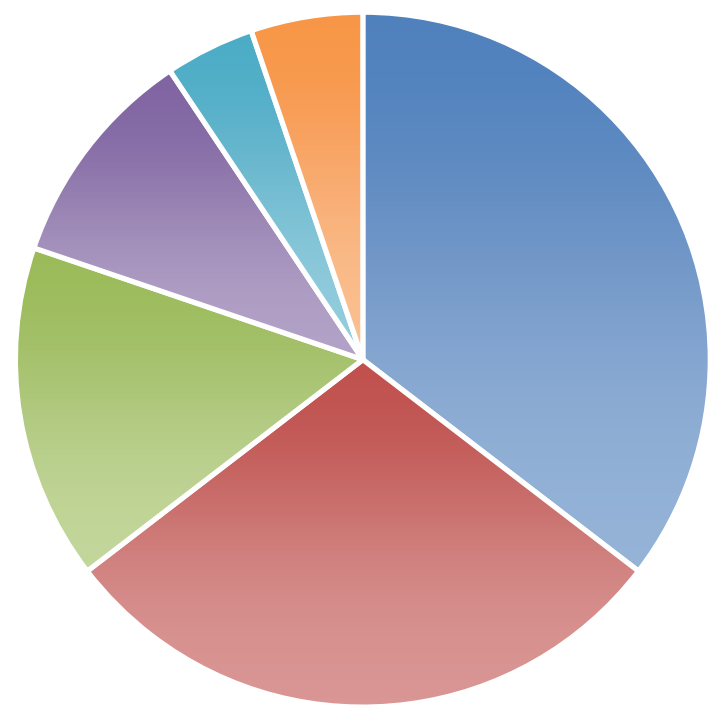

B

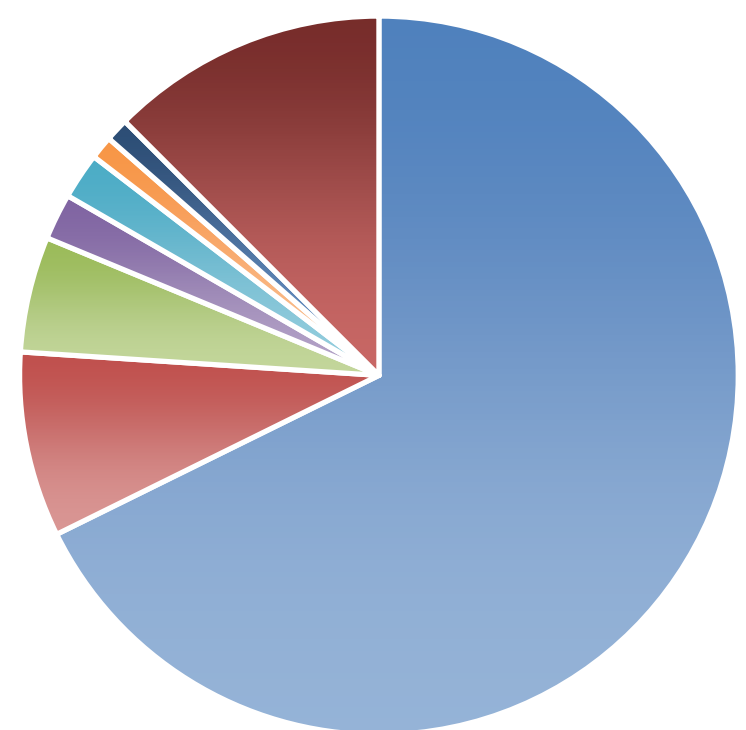

- Photosynthesis 34

- Metabolism 28

- Protein synthesis 15

- Transport 10

\section{- Defense 4}

Signal transduction and Cellular biogenesis 5

- Chloroplast 65

- Cytoplasm 8

- Mitochondria 5

- Membrane 2

- Cytoskeleton 2

- Extracellular 1

- Endoplasmic reticulum 1

- Unknown 12

Figure 4: Gene ontology classification of water stress responsive proteins according to their (A) biological function and, (B) location in the cell categories as per the annotation in the Viridiplantae taxonomic databases. 


\section{A. Protein Synthesis / modification}
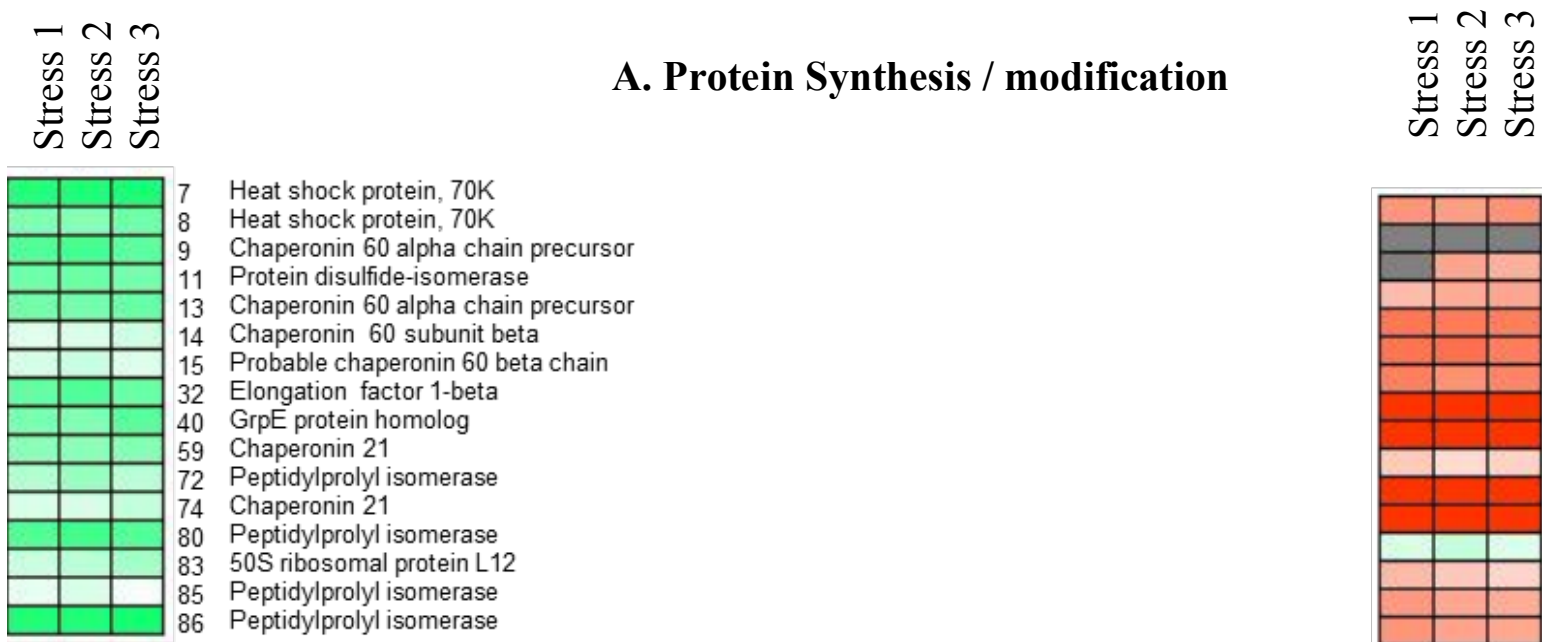

7 Heat shock protein, $70 \mathrm{~K}$

8 Heat shock protein, $70 \mathrm{~K}$

9 Chaperonin 60 alpha chain precursor

11 Protein disulfide-isomerase

13 Chaperonin 60 alpha chain precursor

14 Chaperonin 60 subunit beta

15 Probable chaperonin 60 beta chain

32 Elongation factor 1-beta

40 GrpE protein homolog

59 Chaperonin 21

72 Peptidylprolyl isomerase

74 Chaperonin 21

80 Peptidylprolyl isomerase

8350 S ribosomal protein L12

85 Peptidylprolyl isomerase

86 Peptidylprolyl isomerase

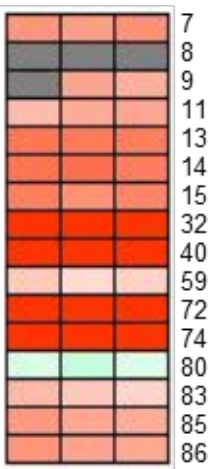

\section{B. Photosynthesis}

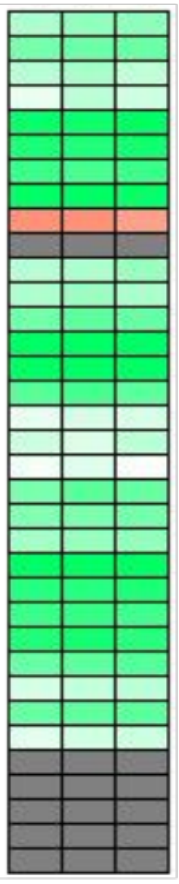

1 Ribulose 1,5-bisphosphate carboxylase-oxygenase large subunit 2 Sedoheptulose biphosphate

3 Ribulose 1,5-bisphosphate carboxylase-oxygenase large subunit 16 Phosphoribulokinase

22 Ribulose 1,5-bisphosphate carboxylase-oxygenase large subunit

23 Ribulose 1,5-bisphosphate carboxylase-oxygenase large subunit

24 Ribulose 1,5-bisphosphate carboxylase

25 Ribulose 1,5-bisphosphate carboxylase-oxygenase large subunit

26 Ribulose 1,5-bisphosphate carboxylase-oxygenase large subunit

27 Ribulose 1,5-bisphosphate carboxylase-oxygenase large subunit

29 Glyceraldehyde-3-phosphate dehydrogenase (NADP) (phosphorylating) A, chloroplast

31 Ribulose 1,5-bisphosphate carboxylase activase isoform1

33 Ribulose-bisphosphate carboxylase activase

35 Rubisco activase

36 Ribulose 1,5-bisphosphate carboxylase-oxygenase large subunit

41 Sedoheptulose-bisphosphatase (EC 3.1.3.37) precursor

42 Sedoheptulose bisphosphatase

43 Probable photosystem II stability protein HCF136

55 Photosystem II oxygen-evolving complex protein 1

56 Photosystem II oxygen-evolving complex protein 1

57 Chlorophyll a/b-binding protein precursor

58 Ribose-5-phosphate isomerase precursor (EC 5.3.1.6)

60 Chlorophyll a/b-binding protein precursor

61 Chlorophyll a/b-binding protein precursor

62 Photosystem II type II chlorophyll a/b binding protein

67 Glyceraldehyde-3-phosphate dehydrogenase (NADP) (phosphorylating) A

68 Glyceraldehyde-3-phosphate dehydrogenase (NADP) (phosphorylating)A,

76 Photosystem II oxygen-evolving complex protein 2

77 Chlorophyll a/b-binding protein type III (Fragment)

81 Ribulose-bisphosphate carboxylase small chain

84 Ribulose-bisphosphate carboxylase small chain precursor

88 Glyceraldehyde-3-phosphate dehydrogenase (NADP) (phosphorylating) A, chloroplast

90 Chlorophyll a/b-binding protein type III (Fragment)

91 Chlorophyll a/b-binding protein type III (Fragment)

92 Photosystem II oxygen-evolving complex protein 2

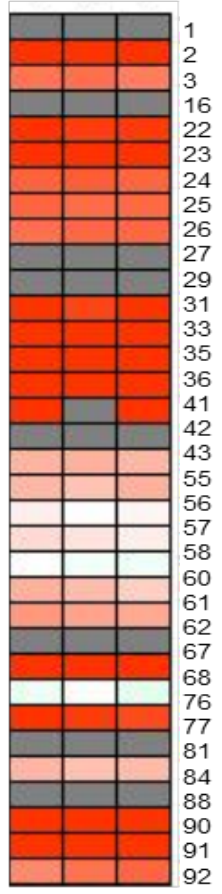

\section{Defense}

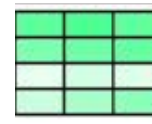

17 Beta tubulin

66 Chitinase class II

73 Peroxiredoxin precurso

75 Ascorbate peroxidase

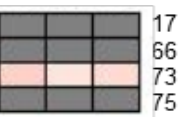




\section{DT (Vemana)}

DS (Florunner)

\section{Signal Transduction}
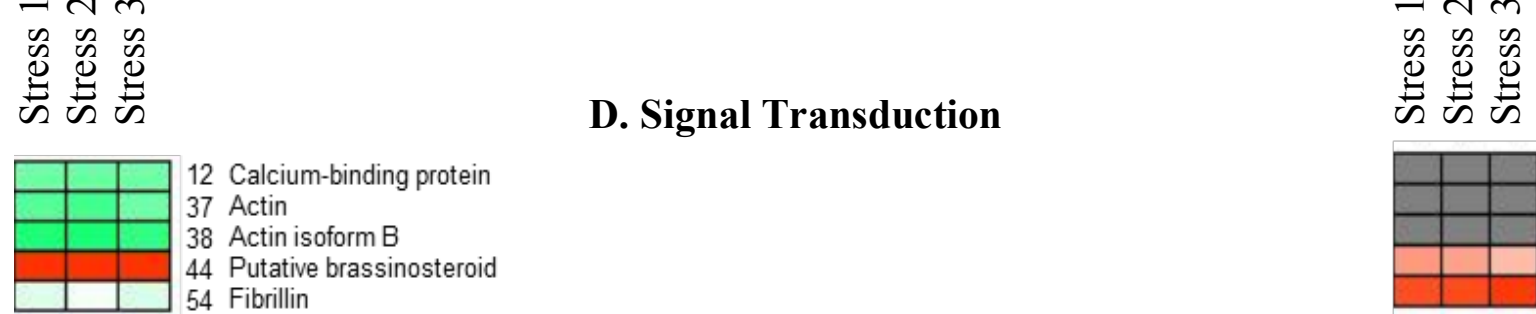

12 Calcium-binding protein

37 Actin

38 Actin isoform $B$

44 Putative brassinosteroid

54 Fibrillin

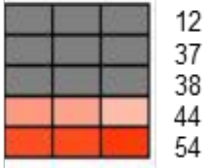

\section{E. Metabolism}

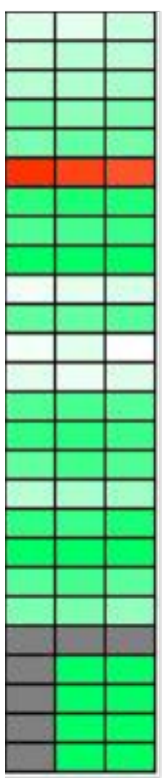

4 Plastid transketolase

5 Probable glycine dehydrogenase

6 Methionine synthase

34 14-3-3-like protein

39 Glutamate-ammonia ligase

46 Probable fructose-bisphosphate aldolase

47 Probable fructose-bisphosphate aldolase

48 Probable fructose-bisphosphate aldolase

49 Probable fructose-bisphosphate aldolase precursor

50 Probable fructose-bisphosphate aldolase precursor

51 Carbonic anhydrase

52 RNA-binding protein

63 Carbonate dehydratase precursor chloroplast

64 Putative quinone oxidoreductase

65 Triosephosphate isomerase

69 Triosephosphate isomerase

70 Carbonic anhydrase

71 Glycine-rich protein

78 Putative quinone oxidoreductase

79 Carbonate dehydratase precursor chloroplast

87 Glycine-rich protein

89 Triosephosphate isomerase

B1 Serine/threonine protein phosphate PP1

D5 Choline monooxygenase

E6 Peroxidase 43

H1 SNF 1 related protein kinase regulatory subunit beta-2

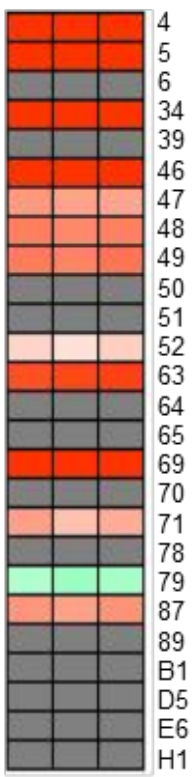

\section{F. Transport}
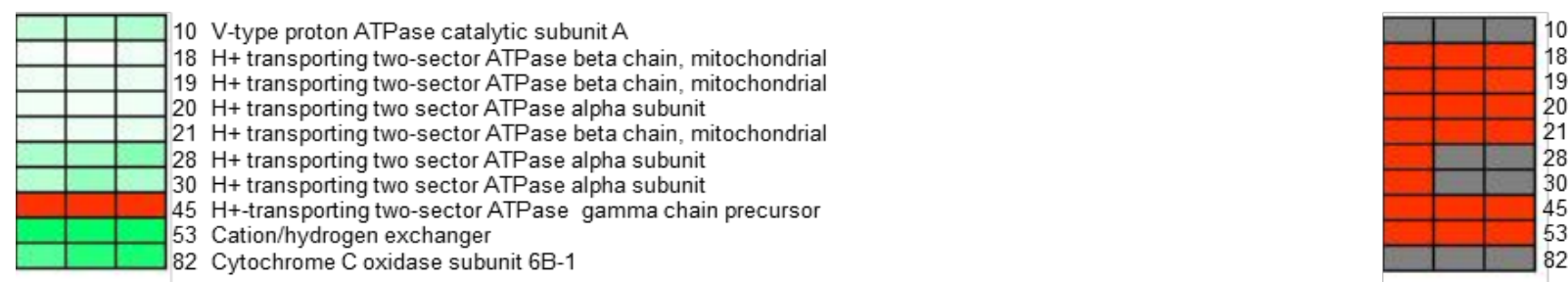

Figure 5: Protein profiles of functional groups during water stress. Heat map of the log 2 relative abundance of proteins through the stress was created using Genesis v1.0 with the MS/MS quantitative data. For each protein, the sequence description assigned with BLAST2GO is provided. Proteins are grouped according to their role in cellular processes. Each block represents time course (from left to right; control, Stress 1 (3-day), Stress 2 (7-day) and, Stress 3 (15-day). Blocks in grey indicate absence of the corresponding protein. 


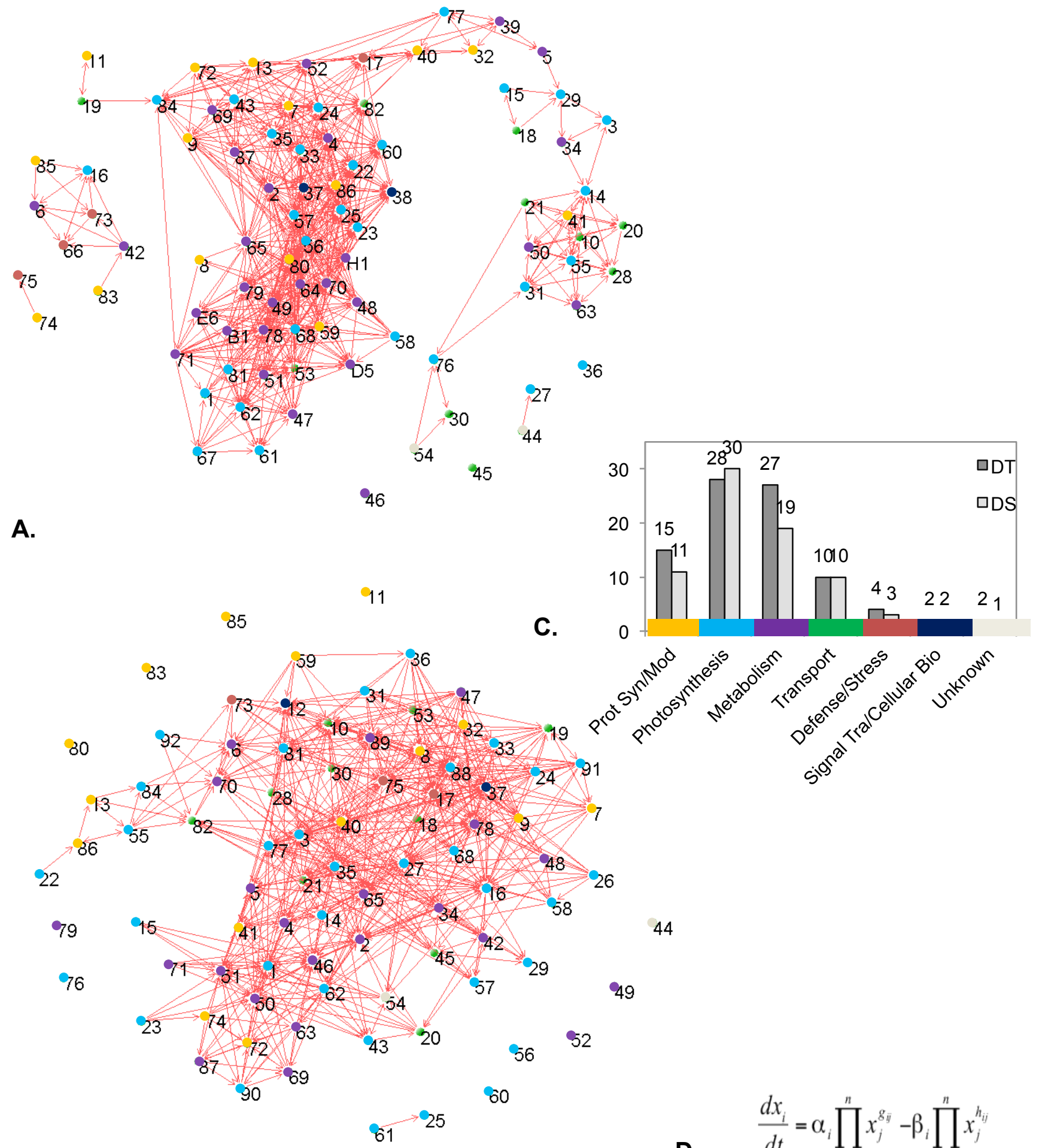

B.

Figure 7: Protein interactions in DT and DS cultivars. Functional group of each protein is indicated in different colors. A: Protein interactions in DT peanut showing more interactions compared to DS (B). The number of interacting proteins involved in various biological functions is shown in C. More proteins involved in protein synthesis and metabolism are associated with interactions in DT cultivar than DS. D. Formula used to determine the interaction of proteins. The estimated interactions were evaluated based on a goodness-of-fit calculated from "multiplecorrelation coefficient" $(R)$ between an expression profile and simulated profile of a protein positioned on the downstream side of an interaction. Significant interactions of individual proteins were indicated based on the first deciles (top 10\%) of multiple co-relation co-efficient $\mathrm{R}$. For each protein, we calculated the average of the $\mathrm{R}$ corresponding to the interactions that the protein regulated the expression of the other proteins and determine the intensity of their interactions between the proteins, Where: $x_{i}:{ }^{\text {th }}$ protein expression; ${ }_{i} i^{\text {th }}$ protein production velocity coefficient; $g_{i j:}$ : coefficient of $i^{\text {th }}$ protein production velocity and $j^{\text {th }}$ protein expression; $;$ i $i^{\text {th }}$ protein degradation velocity coefficient; $h_{i j}$ : coefficient of $i^{\text {th }}$ protein degradation velocity and $j^{\text {th }}$ protein expression. 

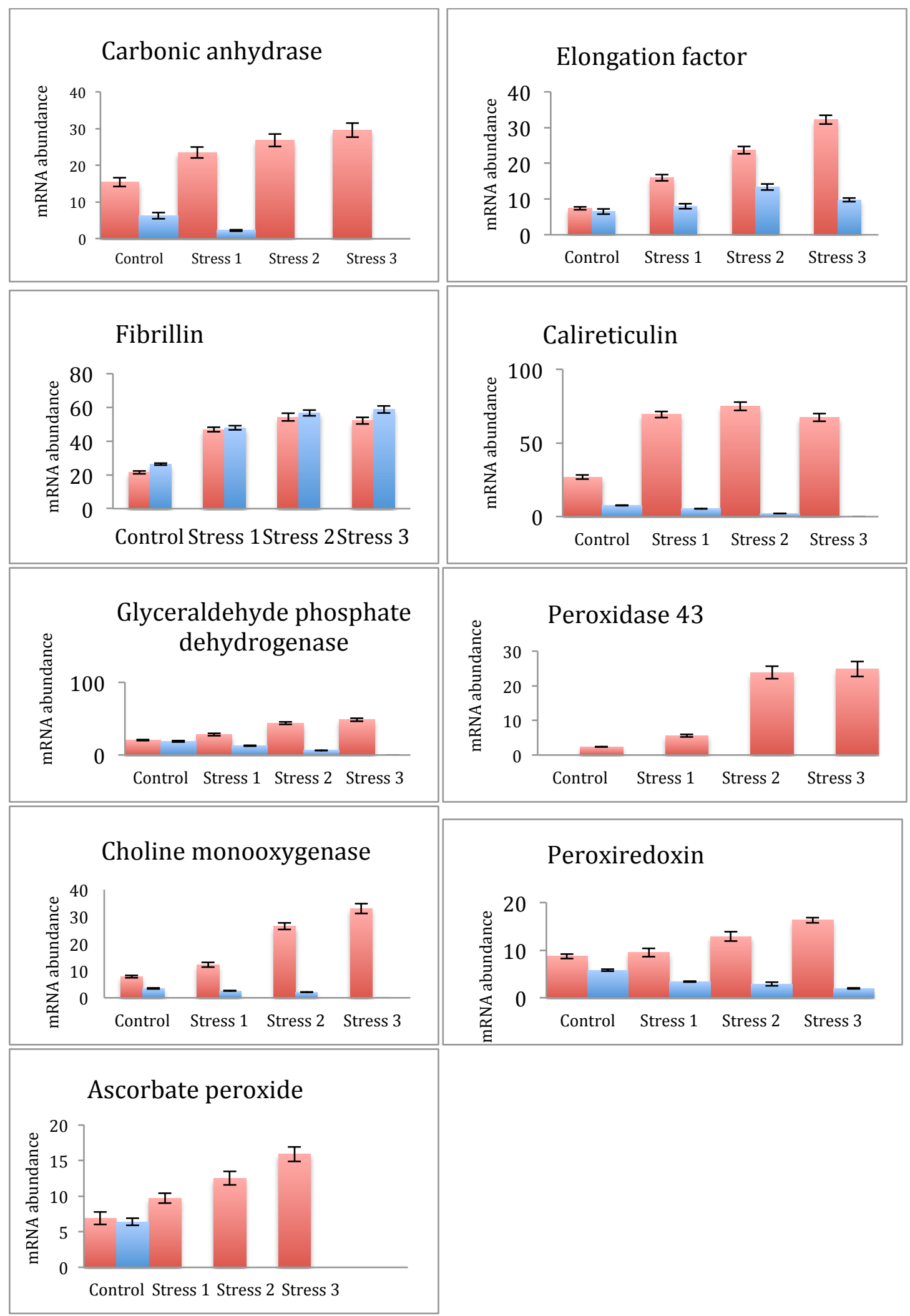

Figure 8: Effects of water stress on mRNA expression levels of key genes in peanut leaf. Relative mRNA abundances were normalized against actin gene abundance. Stress 1: 3 days, Stress 2: 7 days, and Stress 3: 15 days water withholding respectively. 
3

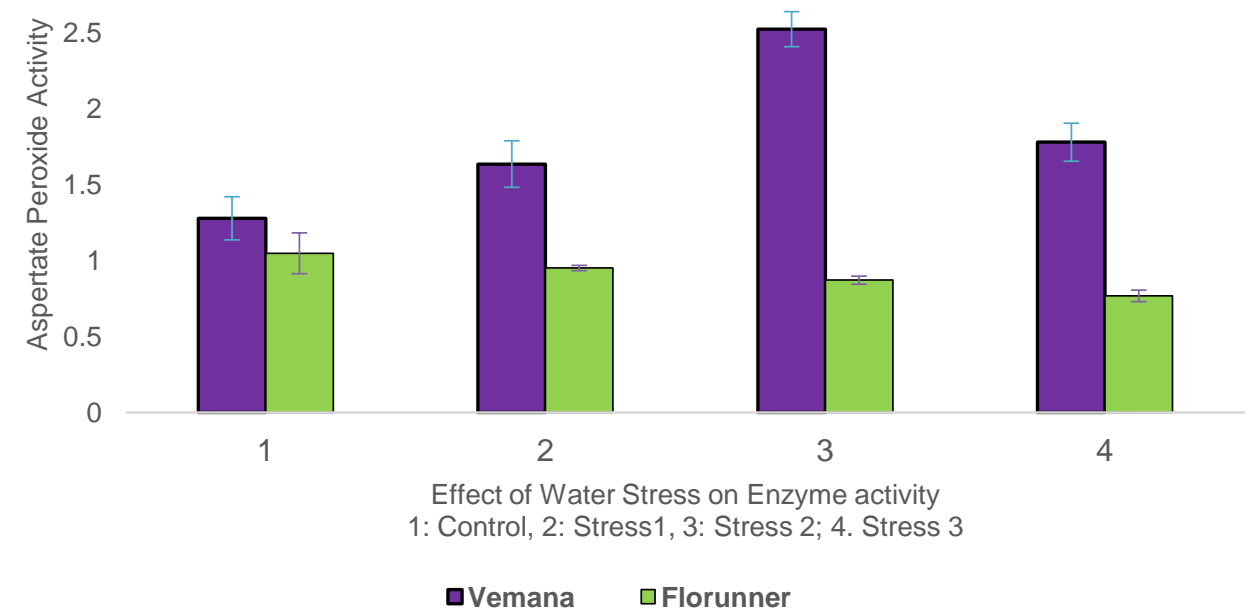

Figure 9: Effects of water stress on expression levels of key genes in peanut leaf. Relative mRNA abundances were normalized against actin gene abundance. 


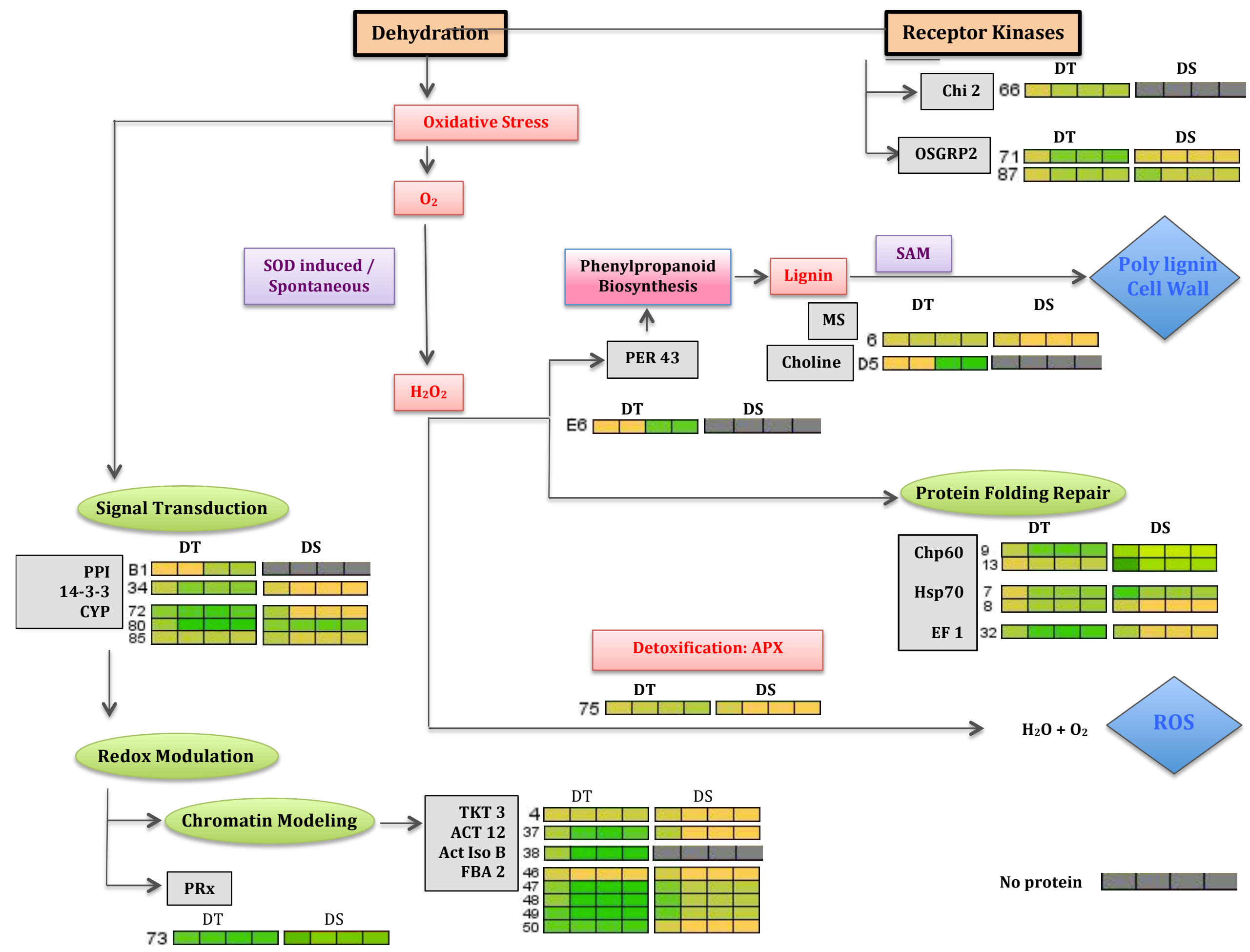

